\title{
NEDOSTAVĚNÝ HRAD NA HRADISKU (OKRES BLANSKO) VE SVĚTLE VÝZKUMU STARÝCH CEST V OKOLÍ SVITÁVKY
}

\author{
PAVEL BOLINA
}

\begin{abstract}
Abstrakt: Existuje jen málo jednoznačně nedokončených staveb hradů z druhé poloviny 13. století. I když lokality tohoto druhu většinou zůstávaji bez výraznějšich archeologických nálezů, či dokonce zděných konstrukcí, je opuštění staveniště samo o sobě jevem, který si zasluhuje pozornost. Téměr vždy postrádáme písemné prameny zdůvodňujici marné vynaložení prostredků i lidské práce, a tak se badatelé uchyluji k nepřmím informacím, z nichž na prvním mistě stoji zprávy o majetkových transakcích (prodej či připojení dotyčného území $k$ většimu celku), nebo úvahy o osobnich di̊vodech na straně stavebnika (smrt, presidlení apod.). K zajímavým výsledkům ale také může vést průzkum starých cest, pokud se podaři zjistit, jaké komunikačni souvislosti měla nedokončená hradni stavba.
\end{abstract}

Klíčová slova: raný a vrcholný středověk - staré cesty - hrady - Sebranice - Svitávka - Kunštát - páni z Holštejna.

\section{An unfinished castle at Hradisko (Blansko district) in the light of research into old routes around Svitávka}

Abstract: There are few definitely unfinished castle constructions dating from the second half of the 13 th century. Although the locations of this kind typically yield scarce archaeological evidence, or even masonry structures, the deserted construction sites are phenomena deserving attention. Invariably, there exist no written sources explaining the futile building activity and human work; as a result, researchers use indirect information, the most important being property transactions reports (sale or the affiliation of the site to a larger unit), as well as reflections on the personal reasons on the part of the investor (death, relocation, etc.). Further interesting results might come from the investigation of old routes provided it is possible to disclose the communication connections of the particular unfinished castle.

Key words: early and high Middle Ages - old routes - castles - Sebranice - Svitávka - Kunštát - Lords of Holštejn.

Tak zvané Hradisko u Kunštátu, ${ }^{1}$ nacházející se v jižní části katastru obce Nýrov (okr. Blansko) protilehlé ke vsi Újezd u Kunštátu, pod jejímž jménem je v literatuře také uváděno, představuje nesmírně zajímavou lokalitu (obr. 1). Její pojmenování Hradischka se objevuje již na I. vojenském mapování z druhé poloviny 18. století (obr. 2), valy a př́íkopy Hradiska zmiňuje vlastivědná a místopisná literatura od konce 19. století (Tenora 1885, 2; 1903, 173; Šimák 1917, 168; Hosák 1931, 18), aniž by se jakkoliv mohla pokoušet o určení doby, kdy fortifikace asi vznikla. Teprve A. Štrof (1987a, 87) navrhl možnost, že Hradisko fungovalo jako raně středověké centrum tzv. sebranického újezdu, darovaného břevnovskému klášteru dle starého klášterního falza roku 1043 bílinským kastelánem Eppem (CDB I, 351-352 č. 378), což se mu však při sondáži lokality nepodařilo prokázat.

Myšlenku A. Štrofa o souvislosti Hradiska u Újezdu se Sebranicemi novým způsobem uchopil M. Plaček $(1988,315-318)$, jenž ve fortifikaci rozeznal nedostavěný vrcholně středověký hrad a jeho založení vztáhl k době po roce 1258, kdy břevnovský klášter dle jiného falza sebranický újezd vyměnil s Bohušem, synem Crha z Ceblovic, za jeho ves Sobotovice (CDB V/1, 238-239 č. 149). Stavbu hradu měl zahájit Bohuš z Ceblovic rodu erbu beraních rohů, který se svým bratrem Hartmanem po polovině 13. století začal kolonizaci rozsáhlých oblastí blízké Drahanské vrchoviny (Hosák 1965; Doležel 2003, 123-173; k rodu erbu beraních rohů viz Trampler 1903-1904; Sedláček 1925, 41-42; Pilnáček 1930, 407-408; Hosák 1938, 107-111; Papajík 2007, 9-21). Důvody k opuštění stavby Hradiska spatřoval M. Plaček $(1988,318)$ bud' v odchodu Bohuše z Ceblovic na Olomoucko, kde je později doložen jako maršálek (CDB V/1, 584 č. 392; V/2,

1 Hradisko u Kunštátu (u Nýrova) je psáno vždy kurzívou, aby bylo odlišitelné od stejnojmenné fortifikace Hradisko nad Svitávkou, která se v textu také často objevuje. 


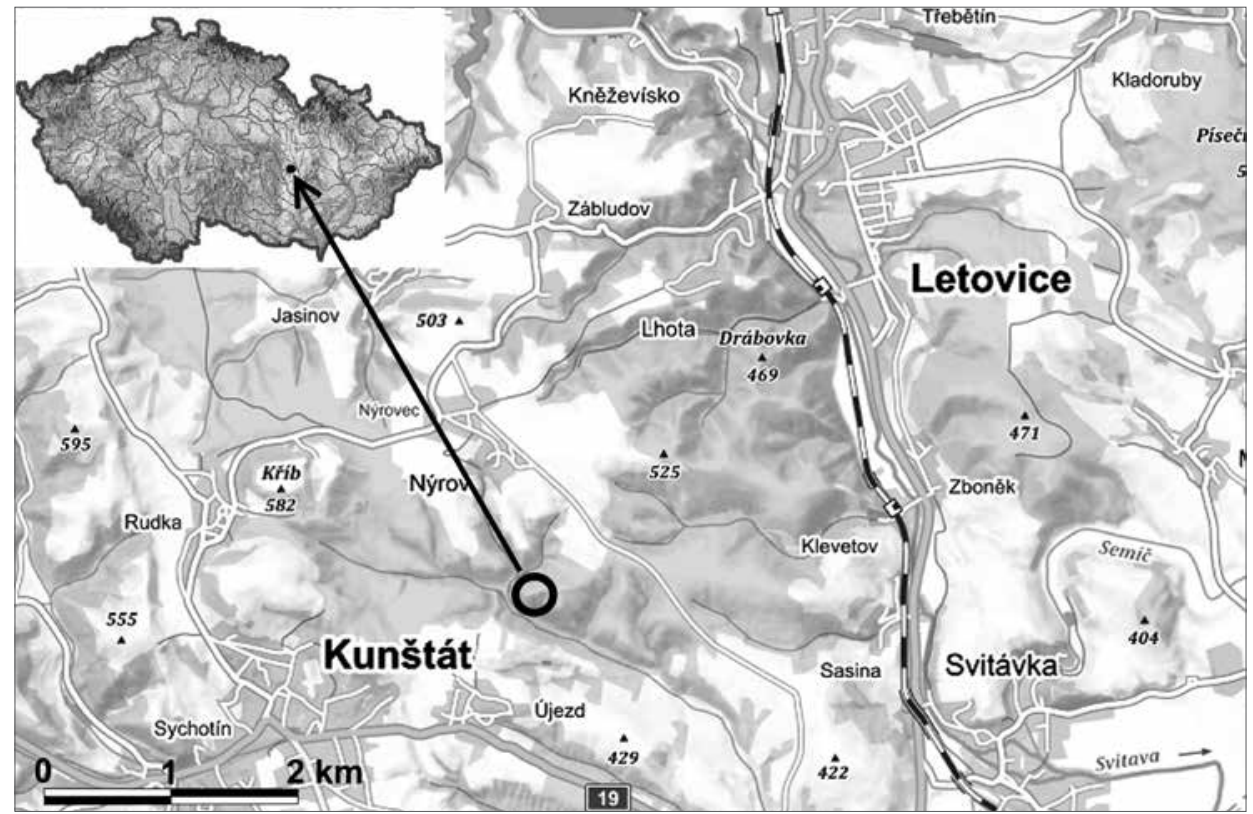

Obr. 1. Vyznačení polohy Hradiska u Nýrova na základní mapě. Mapový podklad http://www.mapy.cz, cit. 10. 9. 2018. Abb. 1. Kennzeichnung der Lage von Hradisko bei Nýrov auf einer Grundkarte. Kartenunterlage http://www.mapy.cz, aufgerufen am 10.9.2018.

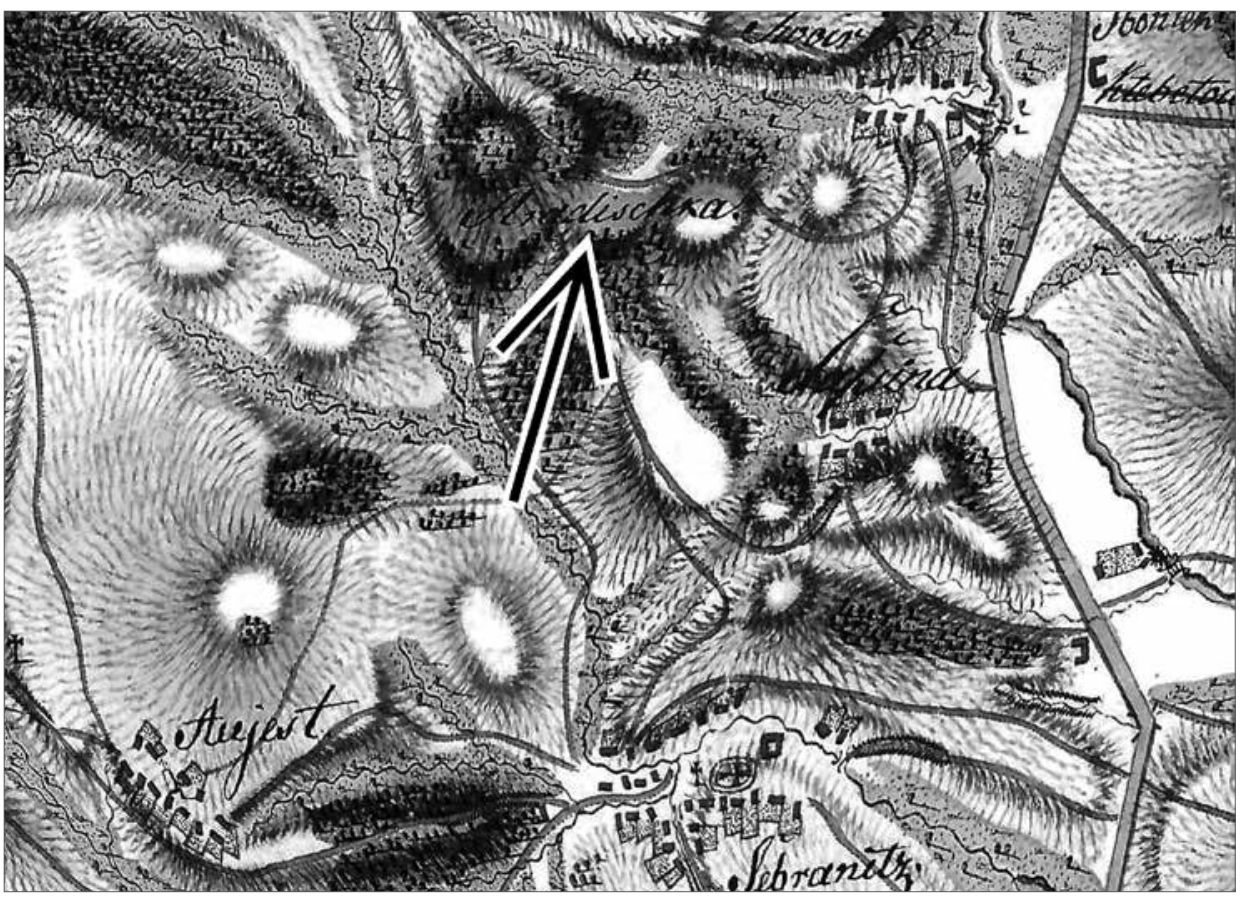

Obr. 2. Vyznačení Hradiska na I. vojenském mapování z let 1764-1768 (šipka). Podklad https://mapire.eu/en/map/europe18century-firstsurvey/, cit. 10. 9. 2018 (vzhledem k nepřesnosti mapy bez měřítka).

Abb. 2. Kennzeichnung von Hradisko auf der I. Militärischen Kartierung aus den Jahren 1764-1768 (Pfeil). Unterlage https://mapire.eu/en/map/europe-18century-firstsurvey/, aufgerufen am 10. 9. 2018 (im Hinblick auf die Ungenauigkeit der Karte ohne Maßstab). 
74 č. 525), nebo ve „ztrátě perspektivy na zisk přilehlého území, jehož se dostalo Kunovi“. Druhou variantu tento autor následně opustil (srov. Plaček 2001, 248), bezpochyby proto, že v mezidobí byly na hradě v Kunštátu zjištěny pozdně románské stavební prvky (Eliáš 1996, 107-118; Plaček 1995, 37-48) dokládající utvoření kunštátského panství ještě předtím, než Bohuš získal sebranický újezd od břevnovského kláštera.

Zdá se však, že svého nesporně přínosného názoru o založení Hradiska Bohušem z Ceblovic se posléze M. Plaček (2010, 87-88) zcela vzdal, nebot' v lokalitě začal vidět kandidáta na ztotožnění s odjinud neznámým hradem Zuzinou, kde jako purkrabí působil roku 1250 Kuna - předek pozdějších pánů z Kunštátu (CDB IV, 336 č. 184: „Chuno castellanus de Zuzinou“). ${ }^{2}$ Zde ale postrádáme vysvětlení, v rámci jaké državy by zeměpanský hrad Zuzinou v místech Hradiska před polovinou 13. století vznikal, když tou dobou v okolí už byla etablována šlechtická panství rodů pánů ze Zbraslavi (Plaček-Futák 2006, 114-115), pánů z Letovic (Bolina 2005, 25-32), př́ípadně i Tasovců (Hosák 1937, 63-69; Plaček 1987, 245-255) a samotný sebranický újezd již od 11. století patřil rajhradským benediktinům, resp. břevnovskému klášteru (CDB I, 351-352 č. 378; Sedláček 1918, 272-273; Bolina 2009, 386). A neexistují ani žádné náznaky, že by panovník Sebranice benediktinům kvůli stavbě hradu odejmul, ${ }^{3}$ držbu sebranického újezdu břevnovským klášterem nezpochybňuje ani citované falzum listiny Přemysla Otakara II., kterou král roku 1258 Břevnovu schvaloval výměnu Sebranic s Bohušem z Ceblovic za jeho ves Sobotovice (CDB V/1, 238-239 č. 149). I když pomineme problematiku mluvy písemných pramenů v podobě listinných falz, jeví se málo pravděpodobným, že by Kunův titul „castellanus de Zuzinou“ se odvíjel od sotva zahájené stavby Hradiska, neschopného vlastní obrany, jehož opuštění ještě před dolámáním čelního příkopu na nejohroženější straně, ve fázi příprav k založení konstrukcí zděných na maltu (viz obr. 3), přesvědčivě ukázal P. Šimeček (2011, 117-121).

Je zřejmé, že pracovně zatím můžeme chápat Hradisko jako nedostavěný hrad Bohuše z Ceblovic, tedy v souladu s názorem předloženým M. Plačkem v roce 2001. Méně přijatelným se ale jeví vysvětlení, kterým tento autor zdůvodňoval opuštění rozestavěného hradu - Bohuš z Ceblovic prý měl ztratit zájem o jeho dokončení kvůli svému působení v Olomouci a zisku úřadu maršálka (Plaček 2001, 248). Zde totiž postrádáme př́íčinnou souvislost; stejně tak bychom mohli říci, že po zisku úřadu se Bohušovy možnosti dokončit stavbu hradu u Újezdu u Kunštátu podstatně zlepšily. Ani Bohušova funkce přerovského kastelána doložená ve falzu k roku 1266 (CDB V/1, 700 č. 472) a s ní patrně související zisk drahotušského panství (CDB V/2, 195 č. 599; V/2, 577 č. 858; V/2, 612 č. 875; Bolina 1988, 157-167) nemusí implikovat ztrátu zájmu o starší majetek v jiné části Moravy. ${ }^{4}$ Lze se proto ptát, zda neúspěch ,projektu Hradisko“ neměl jiné prííčiny.

Jelikož je prakticky nemožné zjistit nový písemný pramen, který by problém osvětlil, a ani archeologický výzkum se nejeví jako příliš perspektivní (viz Štrof 1987a, 87), nabízí se k využití dosud v souvislosti s Hradiskem u Újezdu neuplatněný postup - určení komunikačních vztahů tohoto hradu, nabízející se zvláště díky množství dochovaných pozůstatků starých cest $\mathrm{v}$ jeho okolí (viz např. obr. 9). Nutno podotknout, že stanovování průběhu starých dálkových tras, které přes tuto část Moravy vedly do Čech, patří k „,evergrínům“ historického bádání již od 19. století

\footnotetext{
2 K identifikaci hradu „Zuzinou“ se Svojanovem viz Bolina (2005, 34-35). Přehled názorů, který podává M. Plaček (2010, 87-88, pozn. 21), lze ještě doplnit o hrad Komňu-Zubačov na Uherskobrodsku, jenž je v práci Janiš-Vrla $(2010,359-368)$ navržen jednak na základě podobnosti se jménem Zubačov objevujícím se u Komni až v 16. století, jednak pro velký předpokládaný průměr okrouhlé věže (12,5 m) v čele tohoto jinak nevelkého hradu, která má podle názoru autorů dokládat zeměpanský původ stavby. Ale žádný majetkový rozbor v tomto smyslu nepředkládají, stejně jako nemohou argumentovat dispozičními analogiemi, tedy jiným podobně malým zeměpanským hradem s velkou okrouhlou věží z doby okolo poloviny 13. století v čele (srov. Varhaník 2012, 299-307). Poslední pokus v bakalářské práci J. Nováka (2016, 46-48), kde se klade rovnítko mezi „Zuzinou“ a „Znoim“ (Znojmo), vyznívá nepřesvědčivě jak z hlediska tvaroslovného (u „Zuzinou“ posesivní koncovka „-ov“), tak argumentace možným písařským omylem při opisování, nebot’ obě lokality stojí na př́slušné listině (CDB IV, 336 č. 184) zapsány ve stejném řádku prakticky vedle sebe.

3 Tzv. nucenými směnami se podrobně zabývá J. Žemlička (1998, 502-531), což ovšem není př́ipad Sebranic ve sporu, který Břevnov vedl s olomouckým biskupem Brunem o církevní desátek ze sebranického kostela (a dalších kostelů břevnovského kláštera) i právo dosazovat faráře, jež si biskup nárokoval z titulu patronátního práva nad rajhradským klášterem, které mu údajně udělil král Václav I. (CDB IV, 249-251 č. 150; V/1, 109-112 č. 55); k problematice naposledy Zapletalová (2016, 219-245).

4 Majetkovou angažovanost jednoho šlechtice v různých částech českého království lze dobře studovat na př́ikladu Boreše z Riesenburka (Velímský 2002), ale i u př́islušníků dalších rodů, např. Protivy z Doubravice (srov. Pilnáček 1930, 47-48; Šebánek 1962, 77-93; Procházka-Plaček 1985, 75-79; Wihoda 1992, 11).
} 


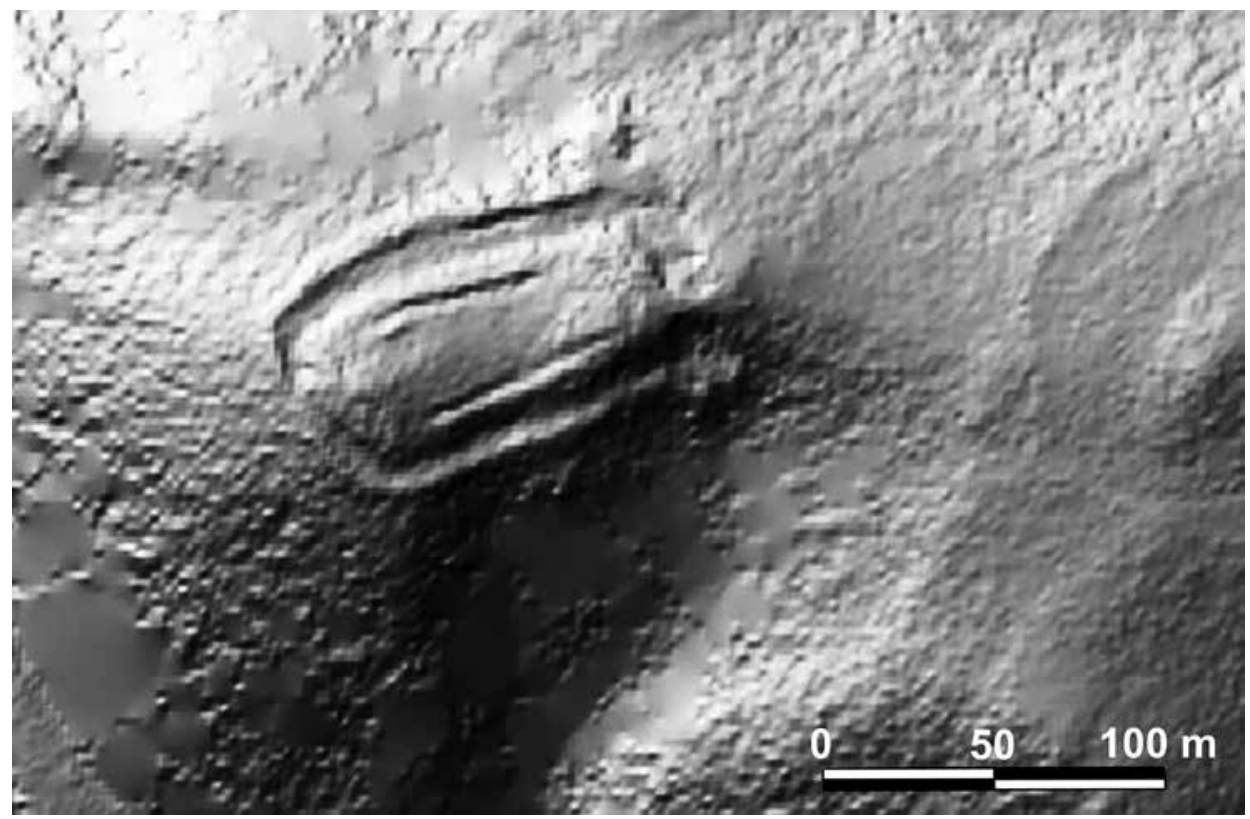

Obr. 3. Hradisko u Nýrova na LIDARu 5. generace (http://www.cuzk.cz, cit. 10. 9. 2018), který dobře zachycuje pozůstatky rýh vykopaných pro založení nikdy nevystavěné zděné obvodové hradby.

Abb. 3. Darstellung von Hradisko bei Nýrov mittels LIDAR der 5. Generation (http://www.cuzk.cz, aufgerufen am 10. 9. 2018), auf der die Überreste der Furchen für das Fundament der nie erbauten Wehrmauer aus Stein gut erfasst werden.

(kritický přehled dosavadní literatury podává K. Severin 2000, 353-388), ale závěry předchozích badatelů nijak konkrétně uchopit problematiku Hradiska neumožňují. Výzkum starých cest se však v posledním desetiletí po stránce metodické i z hlediska dosažených výsledků posunul mílovými kroky (srov. Martínek 2015), což dovoluje přistoupit k tématu Hradiska naznačeným způsobem, a to bez ohledu na skutečnost (nebo právě proto), že některými souvisejícími problémy se autor těchto řádků zabýval již před téměř 15 lety (Bolina 2005, 3-46).

Na začátku je třeba upozornit, že ohledně zpráv písemných pramenů o průběhu starých cest jsme pro okolí Hradiska u Újezdu u Kunštátu ve výjimečné situaci, nebot' k poměrně nevelkému regionu se zde váže několik důležitých a relativně starých informací. Jako první lze uvést již zmíněné falzum listiny k roku 1043, dle kterého bílinský kastelán Eppo daroval břevnovskému klášteru újezd Sebranice, jehož hranici na straně obrácené k hoře Chlum měla tvořit jakási „via publica“ (CDB I, 351-352 č. 378). Další falzum, hlásící se k roku 1073, uvádí mezi primárním nadáním benediktinského kláštera v Opatovicích nad Labem jinak neznámou lokalitu Daletice v Úsobrnsku a újezd Olešnice, ze kterého směrem do Čech měla vycházet blíže neurčená „via“ (CDB I, 370 č. 386). A konečně je zde falzum listiny krále Václava I. k roku 1250 pro klášter Hradisko (u Olomouce), ve kterém se mimo jiné objevuje ustanovení, že mýtný ve Svitávce má ty, kteří by se placení vyhýbali, směrem k Brnu pronásledovat až k ,hoře Jedli“ a směrem k Jevíčku k ,potoku Studená“ (CDB IV, 344 č. 188). ${ }^{5}$

$\mathrm{Z}$ mnoha aspektů informační hodnoty těchto písemných pramenů je pro nás důležité, že jejich výpověd', pokud by ohledně průběhu starých cest neměla být zavádějící, nelze promítat do časů, do kterých se hlásí, nýbrž je třeba ji vztahovat k době skutečného vzniku listin, kdy

5 ,(...) Theloneum furtive vel contumaciter transiens deprehensus, solvat duplum; sequatur autem eum thelonearius Switauie versus Brunnam usque ad montem, qui dicitur V gedli, versus Geuichko vero usque ad aquam, que dicitur Studena (...).“ 
byly v daném znění sepsány. To v př́ípadě pramene „nejstaršího“, břevnovské listiny na újezd Sebranice k roku 1043, byla nejspíše 50. léta 13. století (Šebánek 1953, 269), u listiny opatovické s olešnickým újezdem k roku 1073 to byl konec 12. století (Nový 1991, 136) a u listiny hradišt'ské k roku 1250 doba po roce $1270,{ }^{6}$ či spíše až 80. léta 13. století (Bolina-Šlézar 2006, 307-342). Nejmladší údaje tedy máme ke Svitávce, pro nás do značné míry klíčové lokalitě, která se nachází v místech, kde sevřené údolí řeky Svitavy přitékající od Letovic ústí do Boskovické brázdy.

Koncem 13. století byla Svitávka již trhovou vsí či městečkem kláštera Hradisko (CDB II, 365-367 č. 352; RBM II, 572-573 č. 1324; Procházka 1994, 234; Kuča 2008, 223) a vedla z ní (dle uvedeného falza k roku 1250) cesta do Brna, kterou zde můžeme ztotožnit s trasou zřejmě velmi starého základu, směřující přes Skalici, Jabloňany, Oboru a Bořitov ke Kuřimi (Procházka-Štrof 1983, 49), jejíž průběh z valné části zaznamenává ještě I. vojenské mapování (obr. 4:1). ${ }^{7}$ Ve středověku ke Svitávce nepochybně směřovala také cesta vedoucí po západní straně Boskovické brázdy, přes Býkovice, Žerůtky a Lysice (obr. 4:2), ale i ta se původně u Krhova napojovala na trasu od Bořitova a Obory, takže do Svitávky přicházela rovněž přes Skalici. Až později, někdy koncem 13. či ve 14. století, vzniklo u trasy na západní straně Boskovické brázdy pokračování, které ke Svitávce vedlo přes Voděrady a kolem Sebranic (obr. 4:3; 6:4). ${ }^{8}$ Tato mladší větev severo-jižní trasy však už nesměřovala k raně středověkému jádru Svitávky, představovanému vidlicí cest u kostela sv. Jana Křtitele (Bolina 2005, 8; Kuča 2008, 223), nýbrž v souladu se svým mladším původem těsně míjela Sebranice a přicházela přímo na hlavní svitávecké náměstí (dnešní náměstí Svobody), a to jeho jihozápadním koutem (obr. 8:4). ${ }^{9}$

Problematičtější je ve falzu k roku 1250 určení spojnice Svitávky s Jevíčkem, nejbližším královským městem, jehož význam koncem 13. století musel být značný (Mackerle 1958; Kuča 1997, 626-622; Kejř 1998, 122; Severin 2003, 192; Vích 2013, 112-147). Informace o této vrcholně středověké cestě $\mathrm{z}$ doby po roce 1270 ovšem nic nevypovídá o situaci raně středověké. Nežli se začneme zabývat otázkou, jak a kam se v raném středověku ze Svitávky mohlo jezdit na sever, přidržíme se informací, které nám skýtá falzum k roku 1250. Dozvídáme se z něj, že v 70. či 80. letech 13. století ti, co jeli od Brna na Jevíčko (nebo opačně), měli nějakou možnost se Svitávce vyhnout, ${ }^{10}$ což nepochybně souvisí se situací, že lokalita již nebyla v zeměpanských rukou a postrádala „silový donucovací aparát“ představovaný osádkou Hradiska nad Svitávkou, které tou dobou již bylo tř̌i až čtyři desítky let opuštěné. I když mýtný, který ve Svitávce od pocestných vybíral pro hradišt’ské premonstráty poplatky, jistě nebyl bezmocný, nemohl zabránit tomu, že mnozí z těch, co by jeli přes Svitávku, zvolili jinou trasu, aby placení mýta unikli.

S přihlédnutím k průběhu komunikací zachycených na starých vojenských mapováních je zřejmé, že v krajině této části Boskovické brázdy bylo při pohybu z jihu na sever možné Svitávku minout jen v prostoru východně od ní, což konkrétně pro příchozí od Obory i Lysic znamenalo přebrodit Svitavu mezi Skalicí a Mladkovem, v místě velmi prŕíhodném, a k severu pokračovat na Chrudichromy (obr. 4:4; 5B:1'; 6:1'). Hned za Chrudichromy bylo možné se napojit na cestu vedoucí z Boskovic př́mo na severozápad (patrně na Letovice), jejíž průběh s jen drobnými odchylkami kopíruje dnešní silnice z Boskovic do Míchova (obr. 5A, 5B:5a). Příchozím od jihu, od Skalice, Mladkova a Chrudichrom, umožňovala v Míchově odbočit na severovýchod a k Jevíčku pokračovat po staré cestě přes Podolí a Vísky na Velké Opatovice (obr. 5A, 5B:1a), v kteréžto linii směrem na Drválovice se nacházejí výrazné relikty dopravního pohybu. ${ }^{11}$

\footnotetext{
6 Rozebírají autoři edice v úvodních poznámkách k CDB IV, 341 č. 188.

7 Starý komunikační kontext lze dobře ilustrovat u Obory, kde cesta procházela jen necelý kilometr východně od halštatského hradiště na Malém Chlumu (Štrof 1987, 33; Novák 2015). Ještě těsnějši vazbu na Malý Chlum vykazuje jiná větev trasy od Svitávky (obr. 4:1a), která potok Úmoří, jedinou vodoteč, již bylo nutno mezi Skalicí a Bořitovem přejít, brodila severně od Krhova (relikty komunikace na pozicích WGS-84: N49 2722.4 E16 34 43.3; N49 2716.8 E16 35 17.2). Nad souběhem obou tras ve Skalici nad Svitavou se zdvíhá vrch Hradisko, kóta 341 m (srov. Štrof 1993a, 59).

8 Její relikty západně od silnice Sebranice-Černá Hora zmiňovali na základě upozornění R. Vermouzka již Procházka-Štrof (1983, 48).

9 Také okolnost, že trasa míjí historické jádro Sebranic, hovoří pro její mladší původ. Pokud by měla starší základ, těžko si představit, že by neovlivnila půdorysné uspořádání obce; její centrum by nejspíše vzniklo v místech, kde cesta Voděrady-Svitávka brodila potok Sebránek. 10 Viz výše pozn. 5.

11 Např. WGS-84: N49 32.856 E16 37.870.
} 


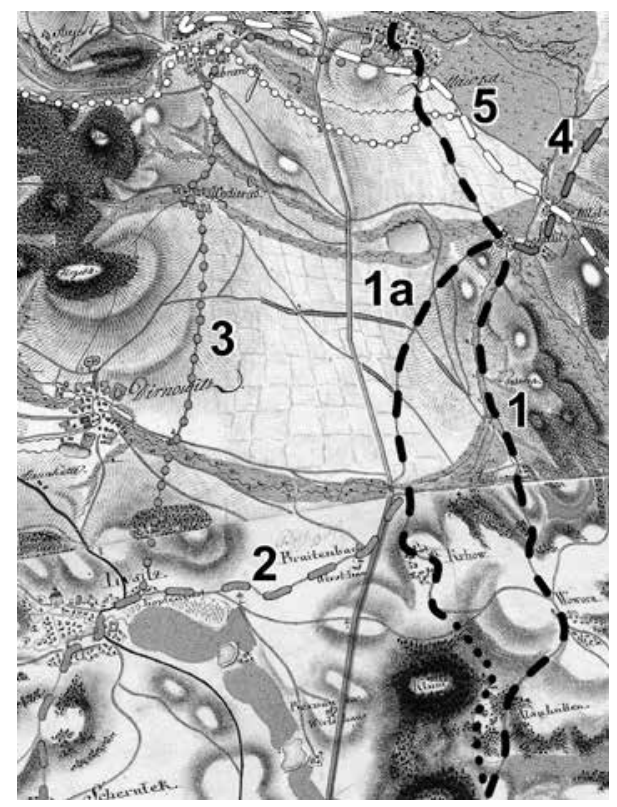

Obr. 4. Průběh starých komunikací jižně od Svitávky na I. vojenském mapování. 1 - raně středověká trasa od Bořitova (přes Oboru, Jabloňany a Skalici) do Svitávky; $1 \mathrm{a}$ - varianta s užší vazbou na pravěké hradiště na Malém Chlumu; 2 - původní napojení komunikace vedoucí po západní straně Boskovické brázdy na trasu (1a); 3 - mladší spojnice trasy vedoucí po západní straně Boskovické brázdy se Svitávkou (kolem Sebranic); 4 - cesta, která na severojižní trase umožňovala vyhnout se Svitávce přes Mladkov a Chrudichromy; 5 - raně středověká východo-západní trasa (tečkovaně - Svitávku míjející zkratka do Kunštátu). Mapový podklad https://mapire.eu/en/map/europe-18century-firstsurvey/, cit. 10. 9. 2018 (vzhledem k nepřesnosti mapy bez měřítka).

Abb. 4. Verlauf der alten Verkehrswege südlich von Svitávka auf der I. Militärischen Kartierung. 1 - frühmittelalterliche Trasse von Bořitov (durch Obora, Jabloňany und Skalice) nach Svitávka; 1a - Variante mit engerem Bezug zum prähistorischen Burgstall auf dem Berg Malý Chlum; 2 - ursprünglicher Anschluss des auf westlicher Seite der Boskowitzer Furche verlaufenden Verkehrsweges an Trasse (1a); 3 -auf westlicher Seite der Boskowitzer Furche verlaufende jüngere Verbindungslinie der Trasse mit Svitávka (um Sebranice); 4 - Weg, der es auf der Nord-Süd-Trasse ermöglichte, Svitávka über Mladkov und Chrudichromy auszuweichen; 5 - frühmittelalterliche Ost-West-Trasse (gepunktet - Svitávka auslassende Abkürzung nach Kunštát). Kartenunterlage https://mapire.eu/en/map/europe-18century-firstsurvey/, aufgerufen am 10. 9. 2018 (im Hinblick auf die Ungenauigkeit der Karte ohne Maßstab).
Osoby vyhýbající se Svitávce měly v Chrudichromech i další možnosti, sice zamířit přímo $\mathrm{k}$ přechodu potoka Semíč pod Bačovem a odtud na Jevíčko cestovat přes Bačov a Pamětice (obr. 5B:1', 5b), ${ }^{12}$ nebo se ještě před brodem o něco výš na potoku Semíč napojili na starou spojnici Boskovic s Jevíčkem (obr. $5 B: 1 ', 4 c, 5 c)$ - pozůstatky její téměř př́mé linie jsou dobře viditelné na II. vojenském mapování, jak procházejí přibližně uprostřed prostoru mezi Bačovem a Sudicemi a dál k Jevíčku vedou příhodným terénem pod Paměticemi, Vanovicemi a Borotínem. ${ }^{13}$ Protože na starých mapováních lze najít spojnice Svitávky ke všem třem výše uvedeným přechodům potoka Semíč (obr. 5A, 5B:4a, 4b, 4c), které vycházejí z cesty vedoucí po jižním úpatí kopce Hradisko (obr. 5A:4), je pravděpodobné, že v době sepsání falza $\mathrm{k}$ roku 1250 (čili po r. 1270) se ze Svitávky na Jevíčko jezdilo po některé ze zmíněných cest, možná po té, co vedla $\mathrm{z}$ Boskovic přímo na Jevíčko (obr. 5B:5c). ${ }^{14}$ Pokud by se tehdy jezdilo ze Svitávky na Jevíčko jinak než po jižní straně Hradiska (obr. 5A:4), nemohl by svitávecký mýtný být vůbec zapojen do kontroly a pokutování těch, co by se Svitávce vyhýbali přes Mladkov a Chrudichromy.

Při tomto řešení se trasa ze Svitávky do Jevíčka nesporně jeví jako sekundární prvek, což také odpovídá situaci, že před polovinou 13. století, kdy město Jevíčko ještě neexistovalo, nebyly ani důvody pro vznik komunikace, která by přesně do prostoru pozdějšího města směřovala. ${ }^{15}$ Tím se ovšem neříká, že by $\mathrm{v}$ raném středověku trasy od Obory a Lysic, když přes Skalici dosáhly Svitávky, neměly návaznost $\mathrm{k}$ severu, jen je třeba počítat i s jinými, Jevíčkem nevynucenými variantami pokračování. ${ }^{16}$ Nepominutelnou roli Svitávky na staré severo-jižní trase ukazuje jak pojmenování lokality podle říčního toku,

12 Viz poloha U pamětické cesty, kterou severně od Bačova zaznamenává mapa Stabilního katastru z roku 1826.

13 I když dál k severu cesta přecházela několik drobných vodotečí, díky přičné svažitosti terénu se jednalo o nekomplikované brody, bez podmáčených ploch $\mathrm{v}$ jejich okolí.

14 „Aqua, que dicitur Studena“ z listiny k roku 1250 se zde jeví jako samotný Semíč u Bačova (srov. Bolina-Šlézar 2006, 310).

15 Mýto v Jevíčku, ve falzech doložené k letům 1256 a 1258 (CDB V/1, 167-168 č. 93; V/1, 254 č. 160), bylo vybíráno na jiné komunikaci (průběhu V-Z, viz Cendelín-Bolina-Adam 2010; Vích-Jílek 2016, 363-380). Toto mýto lze sice promítat i do dřivějších dob a vztahovat snad k raně stř̌edověkému sídlišti u kostela sv. Bartoloměje $1,5 \mathrm{~km} \mathrm{SZ}$ od okraje vrcholně středověkého města Jevíčka (Procházka 1989, 65-66; Vích 2001, 45), ale nelze z jeho existence odvozovat př́mé raně středověké propojení tohoto místa se Svitávkou.

16 Předem ale nelze vyloučit, že prostorem pozdějšího města Jevíčka již v raném středověku procházela nějaká cesta, která by dál k severu pokračovala, např. přes Chornici, Roveň a přechod Třebůvky u Vranové. 
který se zde přecházel ${ }_{17}^{17}$ tak vazba tohoto brodu na fortifikaci nacházející na přilehlém kopci Hradisko $(390 \mathrm{~m})$, jejíž do pravěku sahající původ a význam ve 12. až první polovině 13 . století ukázaly archeologické výzkumy (Štrof 1990, 94-95; 1993, 133-134; Procházka 1994, 231-236; Jarůšková-Štrof 2014, 254-263).

Lze předpokládat, že fortifikace na Hradisku v době svého života, když pravděpodobně ve 12. až první polovině 13. století byla centrální lokalitou podstatné části Malé Hané a přilehlých pásů vrchovin, ${ }^{18}$ přitáhla do Svitávky dopravní pohyb na všech důležitých komunikacích v okolí, aby tam přímo bylo možné ho kontrolovat (vybírat mýto). Problémy, které podle falza k roku 1250 musel řešit svitávecký mýtný, vznikly až poté, co raně středověké Hradisko bylo před polovinou 13. století opuštěno. ${ }^{19}$ Snad právě tehdy Svitávku získal klášter Hradisko i s právem mýta (Procházka 1994, 235), avšak jeho vybírání - jak ukazuje citované po roce 1270 vzniklé falzum - se potýkalo s rychle se měnícím komunikačním schématem okolní krajiny. V rámci jistého „rozvolnění“ tras po opuštění svitáveckého Hradiska mohlo dojít k tomu, že také raně středověká cesta přicházejí od západu přes Sebranice (z Čech), odezvy jejíhož vstupu do Svitávky lze rozeznat na starých mapováních (Bolina 2005, 8; Kuča 2008, 222-223; viz obr. 4:5; 6:2; 8:2), začala Svitávku míjet (obr. 4:5 - tečkovaně; 6:2'; 7:2'). Můžeme proto odmítnout tezi o tom, že v raném středověku se ve Svitávce vybíralo mýto jen od prŕíchozích z Čech (směřujících přes Svitávku na Brno nebo Jevíčko), zatímco ve směru opačném se mělo mýto vybírat až v Čechách, kterou nabídl L. Hosák $(1964,61)$ jako vysvětlení, proč falzum k roku 1250 cestu ze Svitávky na západ nezmiňuje. S tím padá i koncepce s trasou Brněnské cesty k Poličce přes Svitávku, kterou od L. Hosáka přebírali další autoři (srov. Bolina 2005, 7-9, s tam uvedenou literaturou).

Z uvedeného je zřejmé, že ona „via publica“, která ve zmíněném (a bezpochyby až v době po zániku svitáveckého Hradiska vzniklém) falzu břevnovského kláštera k roku 1043 tvořila hranici sebranického újezdu ,versus Chlum“ (CDB I, 351-352 č. 378), ${ }^{20}$ již mohla Svitávku míjet. Dané podmínky beze zbytku splňuje cesta, která směrem na jihovýchod vycházela z prostředku vřetenovitého náměstí v Kunštátu, ${ }^{21}$ aby v trase dnešní silnice II/376 přešla Kunštátský potok. Ještě než se silnice stočí zcela k jihu, na Zbraslavec a Lysice, odbočuje z ní (kunštátskou ulicí Pod Hlubnou) na jihovýchod asfaltovaná cesta, výrazná na všech starých mapováních (obr. 7:2'), která od bývalého zemědělského dvora Podchlumí tvoří katastrální hranici mezi Kunštátem a obcí Újezd u Kunštátu, o níž bezpečně víme, že její území př́íslušelo k sebranickému újezdu břevnovského kláštera, jak ho vymezuje listina k roku 1043 v kombinaci s deskovým zápisem z roku 1368 (ZDO I, 48 č. 975; Bolina 2009, 384-386). Držíc směr stále na jihovýchod do lesa v nižší, pozvolnější části severního svahu zmíněného kopce Chlum $(512 \mathrm{~m})$, cesta dodnes tvoří tutéž hranici. V lesním úseku ji také provázejí pozůstatky starých, setřelých úvozů, přičemž asi pět set metrů od vstupu do lesa cesta míjí pozůstatek výrazného valového útvaru, který by v daném kontextu bylo možné pokládat za objekt související s provozem na komunikaci, snad $\mathrm{s}$ vojenskou či mýtní funkcí. ${ }^{22}$

Vně lesa se pokračování cesty nedochovalo do dnešních dnů, ale z Topografické mapy z konce 50. let 20. století je zřejmé, že vedla do Sebranic (obr. 6:2'). ${ }^{23}$ Kombinací zakreslení na I. vojenském mapování a na mapě Stabilního katastru z roku 1826 lze rekonstruovat i její průběh

\footnotetext{
17 Viz místní jména typu Bělá, Bystřice, Loděnice, Sázava, Strenice, Studená, Teplá, Vrchlabí apod., která všechna se pojí k sídlištím vzniklým na důležitých přechodech stejnojmenných vodotečí (viz Bolina-Klimek-Cílek 2018, 209).

$18 \mathrm{~V}$ 11. století byla tzv. Úsobrnská provincie spravována z knížecího dvora v pozdějších Knínicích, jenž se př́ založení kláštera Hradisko u Olomouce roku 1078 stal součástí základního obvěnění kláštera (CDB I, 83 č. 79; Doležel 2003, 145; Bolina 2005, 13; Vích 2005, 41). S lokalizací knížecího „curia Uzobren“ do Knínic koresponduje i existence samostatné trasy z Čech, která do Knínic směřovala přes Letovice a jíž bude věnována pozornost na jiném místě.

19 Poslední informací, kterou s jistou rezervou můžeme vztáhnout k ještě fungujícímu Hradisku nad Svitávkou, je titul Lamberta z Boskovic, když roku 1240 svědčil jako „Lambertus de Vzoburna“ (CDB III/2, 355 č. 260; viz Bolina 2005, 36, pozn. 216).

20 O identifikaci „Chlumu“ z falza k roku 1043 s kopcem Chlum $(512 \mathrm{~m}) 2 \mathrm{~km}$ ZJZ od kostela v Sebranicích novější literatura již nepochybuje (srov. Procházka-Štrof 1983, 48).

21 Osa vřetenovitého náměstí v Kunštátu (kolmá na cestu přicházející od Sebranic) je ale dána trasou Letovice-Kunštát-Černvír-Žd'árecOsová Bítýška-Tasov-Jemnice (o ní viz Bolina-Cendelín, v tisku), která má evidentně starši původ než cesta ze Sebranic do Kunštátu.

22 WGS-84: N49 29.728 E16 33.013; val není zakreslen na současné Základní mapě, ale zachycuje jej Topografická (vojenská) mapa 1 : 10000 (list M-33-94-C-a-1) z roku 1958, která udává i jeho výšku $3 \mathrm{~m}$.

23 Listy M-33-94-C-a-1 (z r. 1958), M-33-94-C-a-2 (z r. 1959).
} 


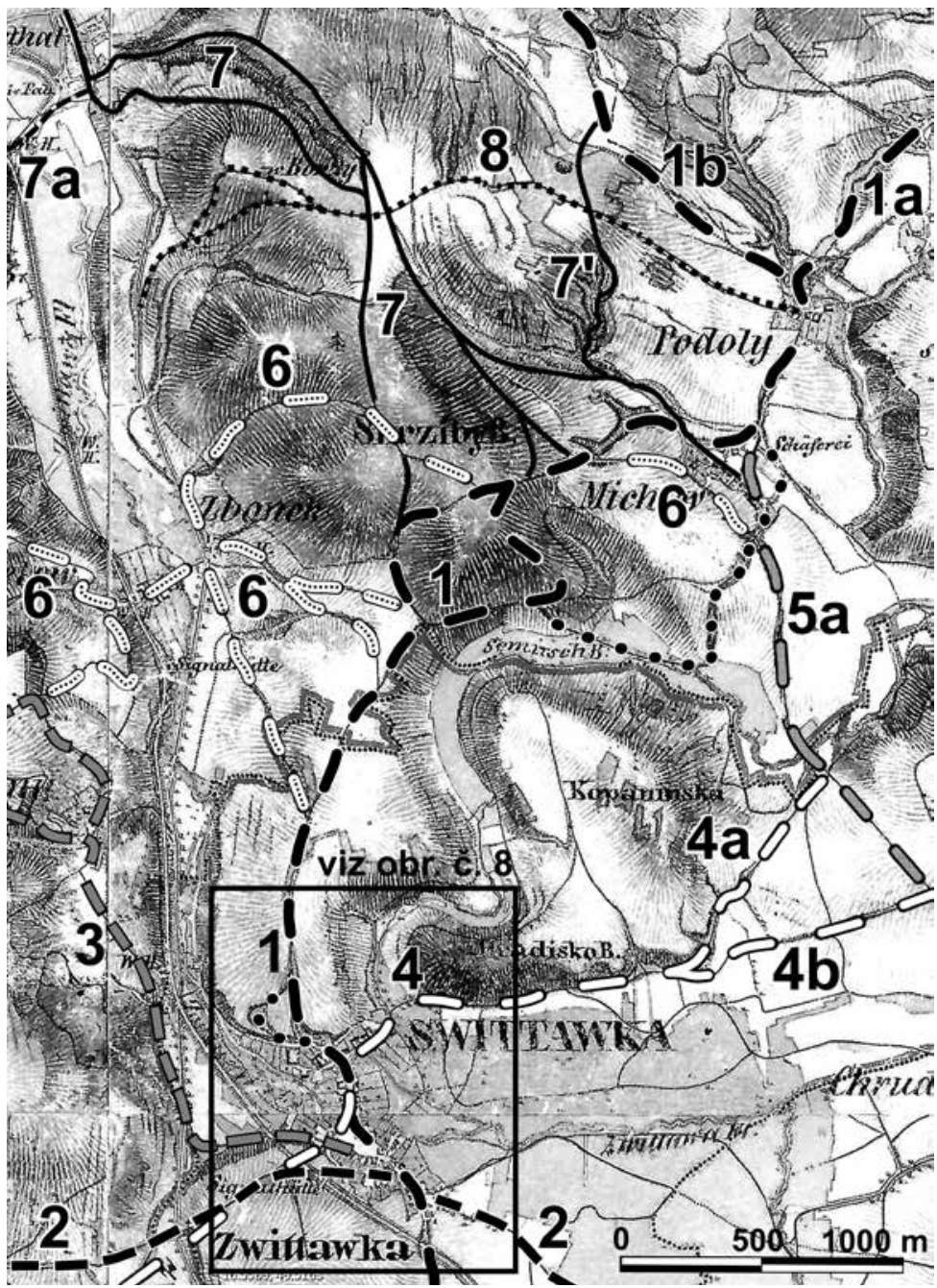

Obr. 5A. Situace pojednávaných tras na sever od Svitávky dle II. vojenského mapování z let 18361842. 1 - raně stř̌edověká trasa pokračující od Svitávky na sever Boskovické brázdy (tečkovaně mladší větev sestupující do údolí Semíče); 1a - pokračování trasy od Svitávky přes Vísky na Velké Opatovice; 1 b - pokračování na Letovice; 2 - raně stř̌edověká východo-západní trasa; 3 - mladší varianta trasy (2) vycházející ze svitáveckého náměstí (na Sasinu); 4 - trasa vedoucí po jižním úpatí Hradiska; 4a, 4b - napojení Svitávky na cestu (5a) vycházející z Boskovic; 5 a - trasa Boskovice-Míchov; 6 - převedení východo-západní trasy (Boskovice-Nýrov) na Zboněk; 7 - mladší varianta cesty do Letovic; 7 a - převedení východo-západní trasy na Lhotu u Letovic; 8 - novověká cesta do Podolí po zprovoznění údolní komunikace Svitávka-Letovice. Mapový podklad https:// mapire.eu/en/map/europe-19century-secondsurvey/, cit. 10. 9. 2018.

Abb. 5A. Situation der behandelten Trassen nördlich von Svitávka gemäß der II. militärischen Kartierung aus den Jahren 1836-1842. 1 - frühmittelalterliche von Svitávka in den Norden der Boskowitzer Furche weiterführende Trasse (gepunktet - jüngerer, zum Tal des Baches Semíč abfallender Zweig); 1a - Weiterführung der Trasse von Svitávka über Vísky nach Velké Opatovice; 1 b - Weiterführung nach Letovice; 2 - frühmittelalterliche Ost-West-Trasse; 3 - vom Marktplatz in Svitávka ausgehende jüngere nach Sasina führende Trassenvariante (2); 4 - am südlichen Fuß des Hügels Hradisko entlang führende Trasse; 4a, 4b - Anschluss von Svitávka an den von Boskovice ausgehenden Weg (5a); 5a - Trasse Boskovice-Míchov; 6 - Umleitung der Ost-West-Trasse (Boskovice-Nýrov) nach Zboněk; 7 - jüngere Variante des Weges nach Letovice; 7a - Umleitung der Ost-West-Trasse nach Lhota bei Letovice; 8 - neuzeitlicher Weg nach Podolí nach Inbetriebnahme der Talstraße Svitávka-Letovice. Kartenunterlage https://mapire.eu/en/ map/europe-19century-secondsurvey/, aufgerufen am 10. 9. 2018. 


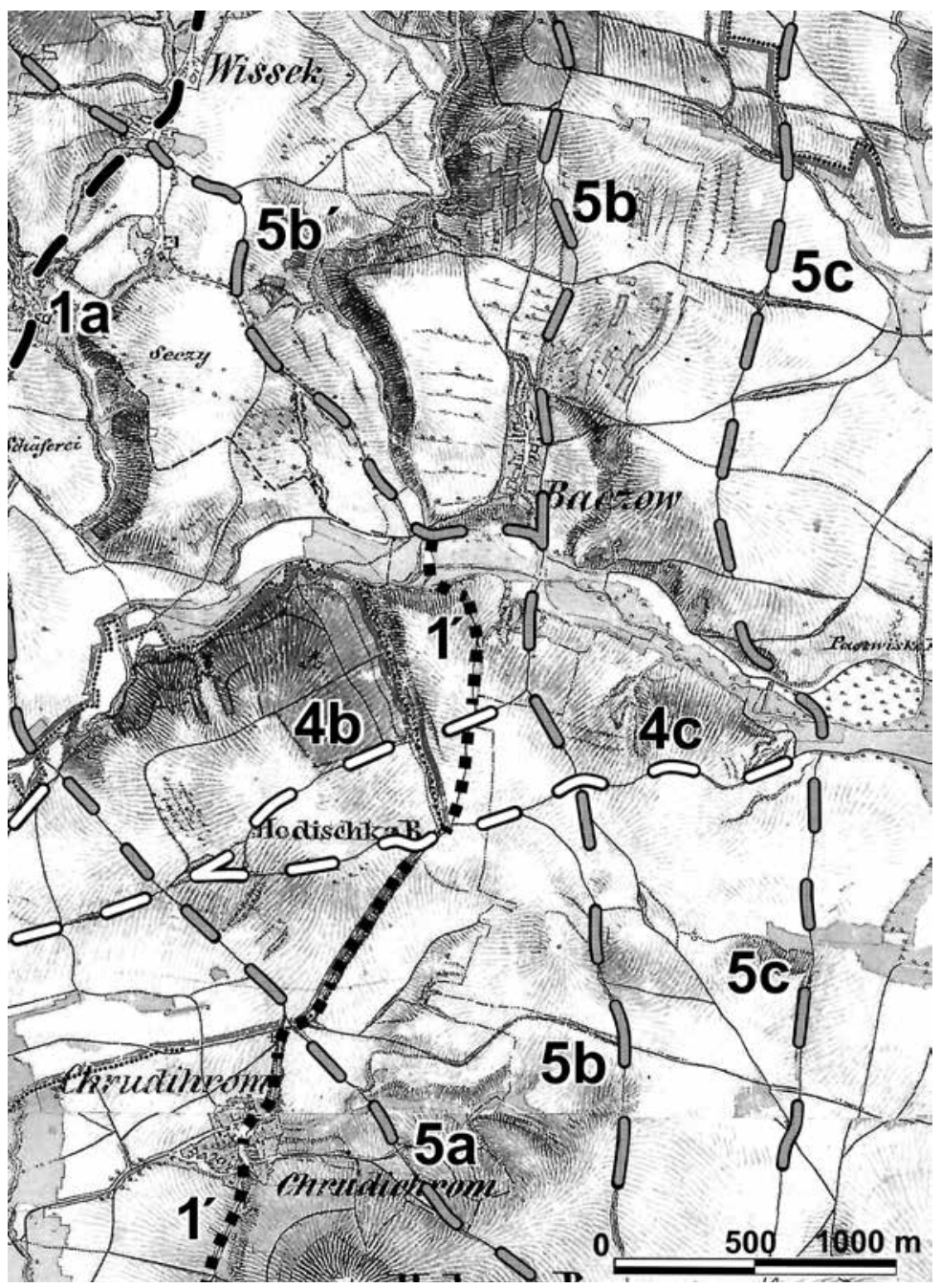

Obr. 5B. Situace pojednávaných tras na severovýchod od Svitávky dle II. vojenského mapování z let 1836-1842. 1a - pokračování raně středověké trasy od Svitávky přes Vísky na Velké Opatovice; 1' - mladší Svitávce se vyhýbající varianta severo-jižní trasy; 4b, 4c - napojení Svitávky na cesty $(5 b, 5 c)$ vycházející z Boskovic; $5 b$ - trasa Boskovice-Bačov-Pamětice; 5b' - odbočka do Vísek a Letovic; $5 \mathrm{c}$ - někdejší prúímá spojnice Boskovic s Jevíčkem. Mapový podklad https:// mapire.eu/en/map/europe-19century-secondsurvey/, cit. 10. 9. 2018.

Abb. 5B. Situation der behandelten Trasse nordöstlich von Svitávka gemäß der II. militärischen Kartierung aus den Jahren 1836-1842. 1a - Weiterführung der frühmittelalterlichen Trasse von Svitávka über Vísky nach Velké Opatovice; 1' - jüngere, Svitávka ausweichende Variante der Nord-Süd-Trasse; $4 \mathrm{~b}, 4 \mathrm{c}-$ Anschluß von Svitávka an den von Boskovice ausgehenden Weg (5b, 5c); 5b - Trasse Boskovice-Bačov-Pamětice; $5 b^{\prime}$ - Abzweigung nach Vísky und Letovice; $5 c$ ehemalige direkte Verbindungslinie zwischen Boskovice und Jevíčko. Kartenunterlage https:// mapire.eu/en/map/europe-19century-secondsurvey/, aufgerufen am 10. 9. 2018.

přes jižní část Sebranic (obr. 4:5 - tečkovaně; 7:2'; 10:2), kde od úrovně kostela Nanebevzetí Panny Marie se pokračování trasy původní cesty překrývá s dnešní silnicí I/19. Podle starých mapování i za křižovatkou se silnicí Svitavy-Brno (E461) cesta od Kunštátu směřovala stále na východ, tvoříc úseky jižní hranice katastru Svitávky. 
Je zřejmé, že vedla k místu nápadného zúžení říční nivy na přechodu Svitavy do Mladkova, které dobře zachycuje I. i II. vojenské mapování (to první i s mostem - viz obr. 4). ${ }^{24} \mathrm{~K}$ němu také směřovala cesta od Svitávky, která se ještě před přechodem řeky spojila s komunikací přicházející od Sebranic (obr. 4:5; 6:2, 2'). Vše ukazuje na to, že nemáme co do činění s trasou na Brno, nýbrž do Boskovic, kam se z Mladkova původně jezdilo přes zalesněný útvar Rovné $(446 \mathrm{~m})$, nebot' údolní terén mezi Rovnou a hřbetem Habří (451 m), kterým vede do Boskovic dnešní silnice II/150, byl dř́ve asi př́liš podmáčený. ${ }^{25}$ Sledování trasy Kunštát-Sebranice-Mladkov, která nás přivedla do Boskovic, dovoluje o cestě objevující se ve falzu listiny k roku 1043 na hranici sebranického újezdu uvažovat jako o komunikaci západo-východního průběhu, která přicházela z Čech a po překonání Boskovické brázdy pokračovala od Boskovic přes Drahanskou vrchovinu na Prostějovsko. ${ }^{26}$ Nelze o ní primárně hovořit jako o cestě do Brna, i když v Boskovické brázdě bylo samozřejmě možné odbočit směrem k jihu na Bořitov po křižující severo-jižní trase, o níž jsme hovořili výše.

$\mathrm{S}$ těmito poznatky můžeme obrátit pozornost k poslednímu a nejstaršímu ze tř́i výše uvedených písemných pramenů - falzu zakládací listiny opatovického kláštera k roku 1073 (CDB I, 370 č. 386), které pro konec 12. století dokládá existenci cesty vycházející z olešnického újezdu směrem do Čech. Zde vyvstává několik otázek, především zda lze v souladu se starší literaturou (zejména Šimák 1917, 166-167) předpokládat, že jde o stejnou komunikaci, která podle zakládací listiny města Poličky z roku 1265 vedla z Vysokého Mýta přes Poličku do Brna (CDB V/1, 673-677 č. 457). A musela ona cesta do Brna z roku 1265 být totožná s cestou, která po polovině 13. století tvořila proti kopci Chlum hranici sebranického újezdu? Proč přitom Olešnice, eponymní lokalita újezdu objevujícího se v písemném prameni z konce 12. století, neleží přímo na trase mezi Poličkou a Svitávkou, ${ }^{27}$ jejíž průběh přes Bystré, Trpín, Ústup a Sulíkov odvodil v roce 1917 J. V. Šimák?

Odpovědi na tyto otázky nabídl Jaroslav Sadílek (ústní sdělení), když před lety u Bedřichova (11 km jižně od Olešnice) nalezl výrazné úvozy, ${ }^{28}$ které následné průzkumy Dušana Cendelína dokázaly vztáhnout $\mathrm{k}$ trase doložené řadou dalších reliktů, směřující z (Moravské) Olešnice téměř přímo na jih k Brnu (jednak přes Zhoř a Kuřim, jednak přes Brtov a Újezd u Černé Hory), tedy podstatně kratším způsobem, než jaký by představovala doposud uvažovaná cesta od Poličky do Brna přes Sebranice či dokonce Svitávku. ${ }^{29} \mathrm{Z}$ toho pro zde sledovanou problematiku vyplývá, že v cestě vycházející z olešnického újezdu směrem do Čech, jak ji koncem 12. století zmiňuje falzum zakládací listiny opatovického kláštera k roku 1073, můžeme vidět komunikaci vzniklou souběhem dvou tras, jedné přicházející od jihu (od Brna přes Bedřichov a [Moravskou] Olešnici) a druhé od východu (od Boskovic přes Sebranice a Trpín).

Zbývá se vrátit do Svitávky a určit, jak se přes tuto lokalitu raně středověká (východozápadní) trasa od Boskovic dostávala na výšiny na rozvodí Křetínky a jižnějších pravobřežních přítoků řeky Svitavy (u Olešnice již rozvodí Křetínky a Svratky). Z podaného rozboru jejího průběhu - Svitávku míjejícího od poloviny 13. století, kdy již svitávecké Hradisko bylo opuštěné,

\footnotetext{
24 Zúžení nivy řeky Svitavy u Mladkova, zachycené na I. vojenském mapování, je důkazem obrovských proměn údolní nivy v 19.-20. století, kdy zmizely dřive vystupující terasy, které umožňovaly přejít vodoteče na místech, kde to později bylo možné jen za pomoci náročných terénních úprav (k problematice viz Bolina-Klimek-Cílek 2018, 53-58; 63-71).

25 Nejvýraznější úvozy „suché trasy“ do Boskovic se dochovaly na výstupu z Mladkova do sedla Úlehle východně od kóty 407,9m, ale pozoruhodné relikty se nacházejí i dál za Rovnou směrem k Boskovicím. Souběh této komunikace s dalšími cestami tvoři v Boskovicích osu Židovského města (srov. Kuča 1996, 200-201). Alternativní a patrně mladší trasa, která vedla při severním úpatí Rovné, ale ještě nad úrovní údolní nivy, již vykazuje vazbu na boskovické Dolní předměstí.

26 V souvislosti s trasami přes Drahanskou vrchovinu zde lze odkázat na jejich detailní zdokumentování v rámci velkého výzkumného projektu NAKI, realizovaného v letech 2011-2014 pod vedením Jana Martínka (po dohodě s ním přistupné na http://naki.vectormap.cz/).

27 Otázka ohledně příčiny téměř tř́ikilometrové vzdálenosti Olešnice od komunikace Ústup-Trpín je legitimní jen za předpokladu kontinuity polohy vrcholně středověké Olešnice minimálně od 12. století (srov. Kuča 2000,574-578). Poloha Olešnice přitom není odvozena od sekundárně k ní převedené cesty od Kunštátu.

28 WGS-84: N49 2815.0 E16 2735.6.

29 V úplnosti trasa Olešnice-Bedřichov-Brn(ěnsk)o zatím publikována nebyla, nelze tak činit ani zde, je však možno odkázat na práci Bolina-Cendelín (v tisku), v níž se některé její úseky objevují v souvislosti s pojednávanou křižující komunikací Letovice-Kunštát-Černvír (srov. pozn. 21). O dávném významu prostoru v okolí křižovatky obou tras (nacházející se při rozvodí Svratky a Svitavy mezi Hlubokým u Kunštátu a Černovicemi) by mohl vypovídat i nedávný mimořádný nález keltského opasku (viz http://www.muzeum-boskovicka.cz/nalez-kompletnihoketskeho-zenskeho-opasku-z-kunstatska/d-1133, cit. 15. 8. 2018).
} 


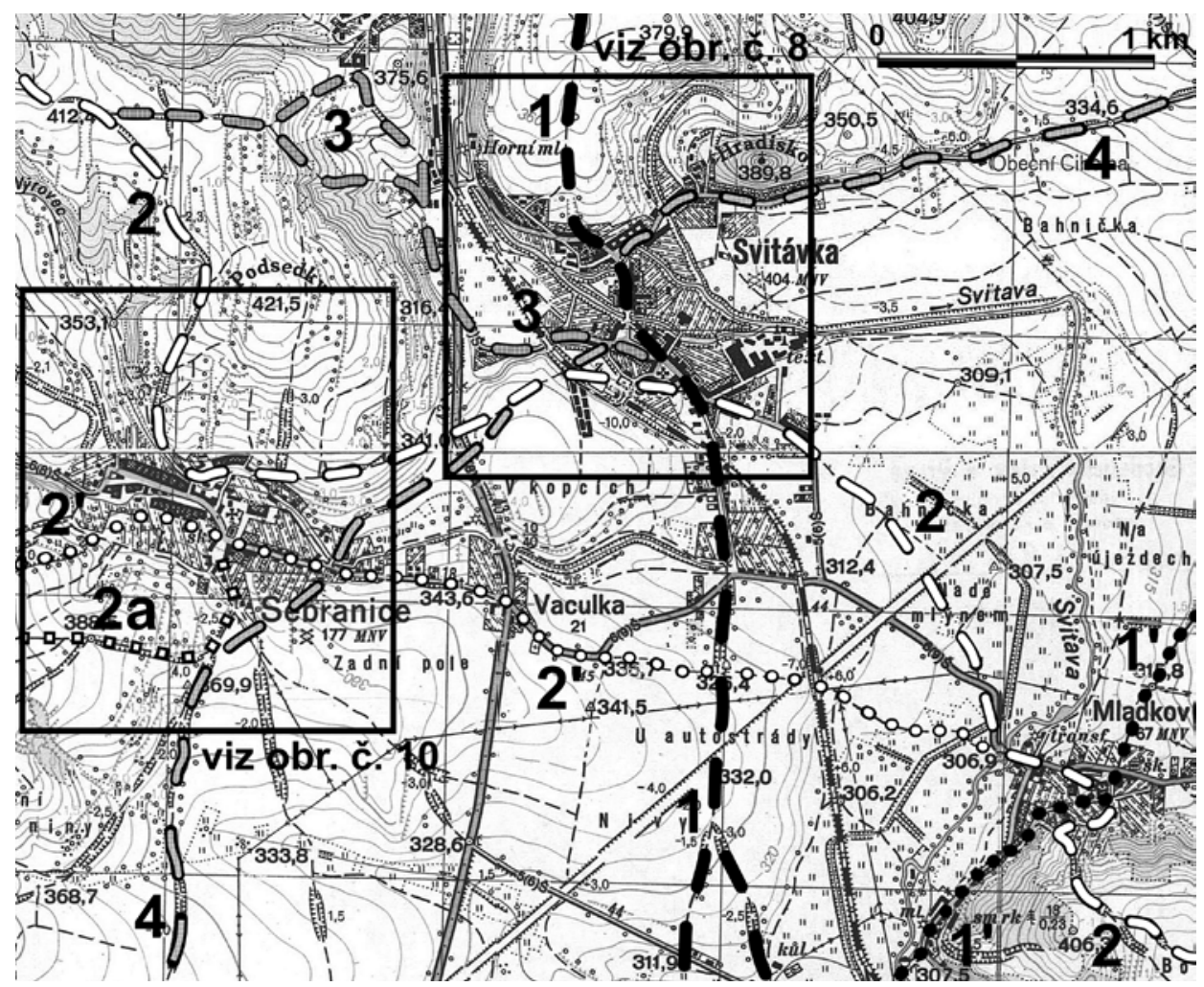

Obr. 6. Situace v okolí Svitávky na Topografické mapě $1: 25000$ z roku 1952. 1 - raně středověká severo-jižní komunikace (trasa Velké Opatovice-Bořitov); 1' - vrcholně středověká varianta severo-jižní trasy umožňující vyhnout se Svitávce přes Mladkov a Chrudichromy; 2 - raně středověká východo-západní trasa (Boskovice-Polička); 2' - vrcholně stř̌edověká spojnice Boskovic s Kunštátem (trasa vzniklá po zániku Hradiska nad Svitávkou); 3 - cesta vycházející ze svitáveckého náměstí na Sasinu (ve funkci varianty trasy č. 2); 4 - vrcholně středověká trasa Lysice-Voděrady-Svitávka-Jevičko. Mapový podklad http://www.cuzk.cz, cit. 10.9. 2018.

Abb. 6. Situation in der Umgebung von Svitávka auf einer topographischen Karte $1: 25000$ aus dem Jahr 1952.1 - frühmittelalterlicher Nord-Süd-Verkehrsweg (Trasse Velké Opatovice-Bořitov); 1' - hochmittelalterliche Variante der Nord-Süd-Trasse, die es ermöglicht, Svitávka über Mladkov und Chrudichromy auszuweichen; 2 - frühmittelalterliche Ost-West-Trasse (Boskovice-Polička); 2' - hochmittelalterliche Verbindungslinie zwischen Boskovice und Kunštát (nach dem Untergang des oberhalb von Svitávka liegenden Burgstalls Hradisko entstandene Trasse); 3 - vom Marktplatz in Svitávka ausgehender Weg nach Sasina (in der Funktion der Variante von Trasse Nr. 2); 4 - hochmittelalterliche Trasse Lysice-Voděrady-Svitávka-Jevíčko. Kartenunterlage http://www.cuzk.cz, aufgerufen am 10. 9. 2018.

dostáváme důležitou informaci, že směrem od Boskovic musela přecházet Svitavu v Mladkově. ${ }^{30}$ Na I. vojenském mapování je také zřetelně vidět cestu vedoucí od mostu přes řeku u Mladkova př́mo k jihovýchodnímu konci Svitávky, před kterým se spojovala s komunikací od Skalice nad Svitavou (tedy výše zmíněnou trasou od Brna - viz obr. 4:1; 6:1,2). Ve Svitávce u kostela sv. Jana Křtitele se obě trasy opět rozdělily (obr. 8:1,2). Zatímco př́chozí ve směru od Skalice na sever teprve čekal přechod řeky Svitavy, cesta od Boskovic, která pokračovala kolem jižní strany svitáveckého kostela na západ (obr. 8:2), měla na delší dobu od přecházení jakékoliv vodoteče klid.

30 R. Slouka $(2005,6)$ o Mladkově a necelých $6 \mathrm{~km}$ vzdálených Drnovicích předpokládá, že představují první dvě položky z výčtu původní majetkové výbavy benediktinského kláštera v Třebiči, který se dochoval v třebíčském rukopisu Kosmovy kroniky: ,(...) Drinouici cum vinea et cum cultore vinee et cum tabernario, Mladcouici, (...).“ (Kosmas, Bretholz, s. 258-259). Starší literatura uvádí, že šlo o jinak neznámé Mladkovice, zaniklé na Třebíčsku, a Drnovice na Vyškovsku (srov. Hosák-Šrámek 1980, 83; 851). 
Směrem na Sebranice se sice přibližovala k potoku Sebránku a svahem pozvolně scházela až téměř k jeho severnímu břehu, ${ }^{31}$ ale jen proto, aby s využitím krátkého úseku zatočené potoční terasy uprostřed dnešních Sebranic nabrala severní směr (obr. 6:2; 7:2; 10:1) a začala stoupat do západního svahu kopce Podseky (kóta 421,8 m), ${ }^{32}$ jehož podstatně strmější východní svah ukončuje údolí Svitavy při vyústění do Boskovické brázdy. Podsedky současně ukončují hřbet mezi údolím Sebránku a údolím krátké bezejmenné vodoteče ústící v Sasině do Svitavy, který vybíhá ze složitě rozvětvené soustavy dlouhých hřbetů rozebíhajících se východně od Nýrova k údolí Svitavy. ${ }^{33}$ A právě konfigurace těchto komunikačně příhodných hřbetů umožnila raně středověké trase od Svitávky po dosažení nadmořské výšky $410 \mathrm{~m}$ v západním svahu Podsedků pokračovat na severozápad, takže na více než tř́íkilometrové vzdálenosti do Nýrova překonávala jen asi stometrové převýšení. Větší stoupání měla cesta jen tam, kde hřbet Podsedků vybíhal z jiného hřbetu, výše položeného, a tam se také dochovaly nejvýraznější pozůstatky trasy v podobě svazků úvozů (obr. 9). ${ }^{34} \mathrm{~V}$ prostoru dnešního Nýrova se severozápadní směr cesty měnil na západní (obr 7:2), ${ }^{35}$ přičemž k dosažení rozvodí nad údolím Křetínky již zbývalo jen projít směrem na Rudku téměř po vrstevnici po severním svahu kopce Kř́íb $(582 \mathrm{~m})$, což je podle všeho hora „Yzar“ z vícekrát zmíněného falza břevnovského kláštera k roku 1043 (Bolina 2009, 386). ${ }^{36}$

Pro téma vytčené v názvu tohoto př́íspěvku má popsaná raně středověká trasa ze Svitávky přes severní část Sebranic k Rudce (a dál na Sulíkov, Ústup a Trpín) zásadní význam (obr. 7:2), nebot' prochází asi 600 metrů před čelem Hradiska (obr. 7:H), ke kterému z ní dodnes asi 1,6 km před Nýrovem odbočuje pohodlná cesta. Jedná se o typickou konfiguraci vztahu hradu a komunikace, kdy př́slušná dálková trasa prochází předpolím fortifikace, jejíž osádka při kontrole dopravního pohybu nemusí překonávat žádné velké překážky, a obvykle ani vzdálenost větší než 1 km (k problematice viz Bolina-Klimek-Cílek 2018, 329). I když je zřejmé, že k budování Hradiska mohl jeho stavebník mít více důvodů, jednu z hlavních příčin zahájení stavby lze spatřovat právě v možnosti kontroly původní raně středověké komunikace Boskovice-Svitávka-Sebranice-Nýrov-Trpín-Polička (obr. 7:2).

I přes známá úskalí retrogresivního využití map Stabilního katastru z první poloviny 19. století (k tomu již Smetánka-Škabrada 1976, 55-60) můžeme na půdorysu Sebranic z roku 1826 dodnes vidět, jak majitel panství reagoval na vznik výše popsané cesty od Boskovic (obr. 10:2), která Svitávku již míjela a po úbočí Chlumu přesměrovala na Kunštát hlavní část dopravního pohybu na východo-západní trase (obr. 7:2'). Zřetelná je snaha převést z ní provoz nejprve kolem kostela (obr. 10:3) na původní trasu od Svitávky, vedenou přes severní část Sebranic a po západním úbočí Podsedků kolem Hradiska na Rudku (obr. 7:2; 10:1).

Se založením nové hlavní, k západu protažené trojúhelné návsi v Sebranicích vznikla dokonce zcela nová cesta, která ze severozápadního koutu návsi vedla př́ímo do předpolí Hradiska (obr. 7:5, H; 10:4). ${ }^{37}$ Pozvolně stoupala západním svahem údolí Sebránku asi o 30 metrů výše, pak přibližně se držíc vrstevnice $380 \mathrm{~m}$ na severozápad a s využitím příhodně nastavených potočních teras se dostala na druhý břeh této vodoteče $\mathrm{k}$ úpatí výrazného hřbetu, pod kterým se dnes nachází objekt bývalé myslivny. ${ }^{38}$ Ze špičky na spodním konci tohoto hřbetu dodnes stoupá

\footnotetext{
31 Na druhém břehu potoka Sebránku pak lze očekávat jádro s nejstarším osídlením Sebranic, což naznačují i výsledky archeologického výzkumu v prostoru bývalé rychty (Kolařik-Merta-Pokorný 2014, 219).

32 Výrazný relikt velkého starého úvozu se nachází vedle dnešní asfaltové cesty na pozici WGS-84: N49 30 04.9 E16 3418.5.

33 Patrně ,montes Chanavi“ z popisu hranice sebranického újezdu ve výše uvedeném falzu k roku 1043 (CDB I, 352 č. 378; Bolina 2009, 386 ).

$34 \mathrm{~V}$ těchto místech cesta přecházela z katastru Sebranic (z trati Meziboří) do katastru Nýrova - poloha svazku úvozů WGS-84: N49 3049.4 E16 3342.1 .

35 Za Nýrovem se sledovaná trasa křižovala s jinou významnou komunikací probíhající Moravou napřič od SV na JZ, kolem které se zformovala dlouhá vřetenovitá náměstí Letovic a Kunštátu (viz výše pozn. 21).

36 Horu „Yzar“ z falza k roku 1043 ztotožňovala většina dříějš̌́ch autorů (např. Šimák 1917, 166; Hosák 1931, 7; Richter 1955, 200-201; Vávra 1971, 97) s polohou Zaharka, kterou zachycuje III. vojenské mapování (toposekce 4157/3), z něj odvozená speciální mapa 1 : 75000 (např. „Boskovice 4257“ z r. 1923) a (jako Zacharku) také „,německá“ vojenská mapa 1: 25000 z roku 1944 (list M-33-94-A-c) při rozvodí Křetínky a Svitavy u nevýrazného návrší, v současnosti označovaného jako Amerika (kóta $597 \mathrm{~m}$ ), a nacházejícího se asi $600 \mathrm{~m}$ JV od kostela v Sulíkově. Proti identifikaci „Yzar" se Zahárkou se vyslovil již A. Sedláček (1918, 273).

37 Současně byla blíže k Rudce na téže cestě asi založena ves Nýrov. Lze tak usuzovat z toho, že další cesta vycházející ze SZ koutu návsi (s průběhem zřejmým na všech starých mapováních) spojila Sebranice se vsí Újezd, vysazenou patrně ve stejné době (viz obr. 7:6).

38 Poloha bývalého brodu pres potok Sebránek WGS-84: N49 3036.9 E16 3332.1.
} 
mohutný úvoz bývalé cesty, po které výše v rozširřené k severu stočené a hustě zarostlé části hřbetu zůstala zachována soustava velkých opuštěných úvozů. ${ }^{39}$ Od nadmořské výšky $470 \mathrm{~m}$ se cesta stáčela k severozápadu a přes sedlo mezi kótou $491 \mathrm{~m}$ a polohou U Hradiska se napojila na původní cestu od Svitávky do Rudky, takže předpolím Hradiska (obr. 7:H) procházela jen ve vzdálenosti asi $500 \mathrm{~m}$ od čela rozestavěného hradu.

K poznání dalších souvislostí se musíme znovu vrátit do Svitávky, kde vidlici cest u kostela sv. Jana Křtitele, ze které dříve se přes Sebranice jezdilo do předpolí Hradiska a dál na Nýrov, znovu opakuje - ale ve větším měřítku - dnešní svitávecké náměstí Svobody, vysazené patrně koncem 13. století klášterem Hradisko (Kuča 2008, 223). ${ }^{40} \mathrm{Z}$ půdorysu zachyceného na mapě Stabilního katastru z roku 1826 je zřejmé, že v době vytyčení náměstí přetrvával význam cesty do Sebranic, která vybíhala ze západnějšího z obou koutů náměstí a záhy se napojovala na původní trasu od svitáveckého kostela do Sebranic (obr. 8:2 - tečkovaně). Při vytyčování svitáveckého náměstí se možná již počítalo i s tím, že určitý úsek cesty do severní části Sebranic bude společný s komunikací, která záhy odbočí k jihu (obr. 8:4) a po přebrodění Sebránku bude po východním okraji Sebranic pokračovat na Voděrady (obr. 4:3; 6:4; 7:4). Šlo o výše zmíněnou variantu severo-jižní trasy po západní straně Lysické sníženiny - pro mladší původ její přes Voděrady vedené větve svědčí kromě vazby na svitávecké náměstí i okolnost, že na ni již půdorys Sebranic nemohl reagovat, a pro cestu tak bylo pohodlnější tuto obec míjet (obr. 10:7). ${ }^{41}$

Ale ze západního koutu svitáveckého náměstí Svobody vybíhala ještě jiná cesta (dnešní Jiráskova ulice - obr. 8:3), pokračující k severu proti toku Svitavy po pravobřežní říční terase (obr. 7:3), již opouštěla asi po $600 \mathrm{~m}$, aby trasou zachycenou ještě na I. vojenském mapování vystoupala do svahu svitavského údolí a přes sedlo západně od kóty $375 \mathrm{~m}$ sešla do Sasiny, ${ }^{42}$ poprvé připomínané roku 1368 jako součást sebranického panství (ZDO I, 48 č. 975). Z uvedené cesty Svitávka-Sasina bylo sice možné se výstupem západně od kóty $375 \mathrm{~m}$ př́mo napojit na komunikaci vedenou k Nýrovu přes Sebranice (obr. 7:3), ale ze Sasiny vedlo několik výhodnějších cest na severněji ležící hřbet, ${ }^{43}$ který končí mnohem pozvolnějšími svahy. Cesta vedená po tomto hřbetu směrem k Nýrovu (obr. 7:8a) již nemusela překonávat žádné větší stoupání, přičemž v nadmořské výšce $482 \mathrm{~m}$ se napojovala na původní komunikaci od Svitávky (přes Sebranice obr. 7:2), po níž se po dalších asi 300 m již procházelo předpolím Hradiska.

V souvislosti se Svitávkou zbývá ještě krátce zmínit pokračování původní raně středověké trasy od Skalice (od Brna) na sever (obr. 4:1), tedy předtím, nežli se ve druhé polovině 13. století prosadila cesta na Jevíčko, která ze Svitávky vedla po jižním úpatí Hradiska (obr. 6:4). Jak již bylo naznačeno, $\mathrm{z}$ vidlice u kostela sv. Jana Křtitele musela tato trasa pokračovat po severní straně kostela do prostoru dnešního náměstí Svobody, vysazeného asi koncem 13. století. S průchodností údolí Svitavy, kam vede cesta ze západního koutu náměstí (obr. 5A:3; 6:3; 8:3), již jsme do Sasiny sledovali v předchozím odstavci, asi nelze pro raný stř̌edověk či dřívější období počítat. Zcela jistě však průběh severo-jižní trasy sleduje severovýchodní strana náměstí Svobody (obr. 8:1), stejně jako ulice Mezimostí, která z jeho severního koutu vybíhá. Za Svitavou z ní téměř kolmo (k SV) odbočovala v linii dnešní ulice Jos. Slavíčka již zmíněná vrcholně středověká cesta do Jevíčka (obr. 8:4), zatímco přirozené pokračování komunikace vycházející z Mezimostí tvoří dnešní ulice Sedláčkova. Ta samotná se dnes stáčí k západu a pokračuje po levém břehu Svitavy proti toku řeky, ale ve směru původní komunikace stoupá do svahu nad Sedláčkovou ulicí mohutný relikt bývalé trasy, ${ }^{44}$ jehož dopravní kontext doplňuje o málo západněji položená serpentina pohodlnější cesty (voznice? - obr. 8:1 - tečkovaně) v trase dnešní Husovy ulice. Asi třicet metrů nad Svitávkou v místech božích muk se obě větve spojovaly do jedné dodnes

\footnotetext{
39 WGS-84: N49 30.859 E16 33.322.

40 Roku 1284 je Svitávka uvedena mezi trhovými vesnicemi, které král Václav II. povoloval hradišt'skému klášteru opevnit (RBM II, 572-573 č. 1324).

41 Viz výše pozn. 9.

42 Úvoz této cesty je nejvýraznější na pozici WGS-84: N49 3037.5 E16 3456.4.

43 Např. úvozy na pozicích WGS-84: N49 3101.8 E16 34 38.2; N49 3052.3 E16 3444.3.

44 WGS-84: N49 3028.3 E16 35 31.4.
} 


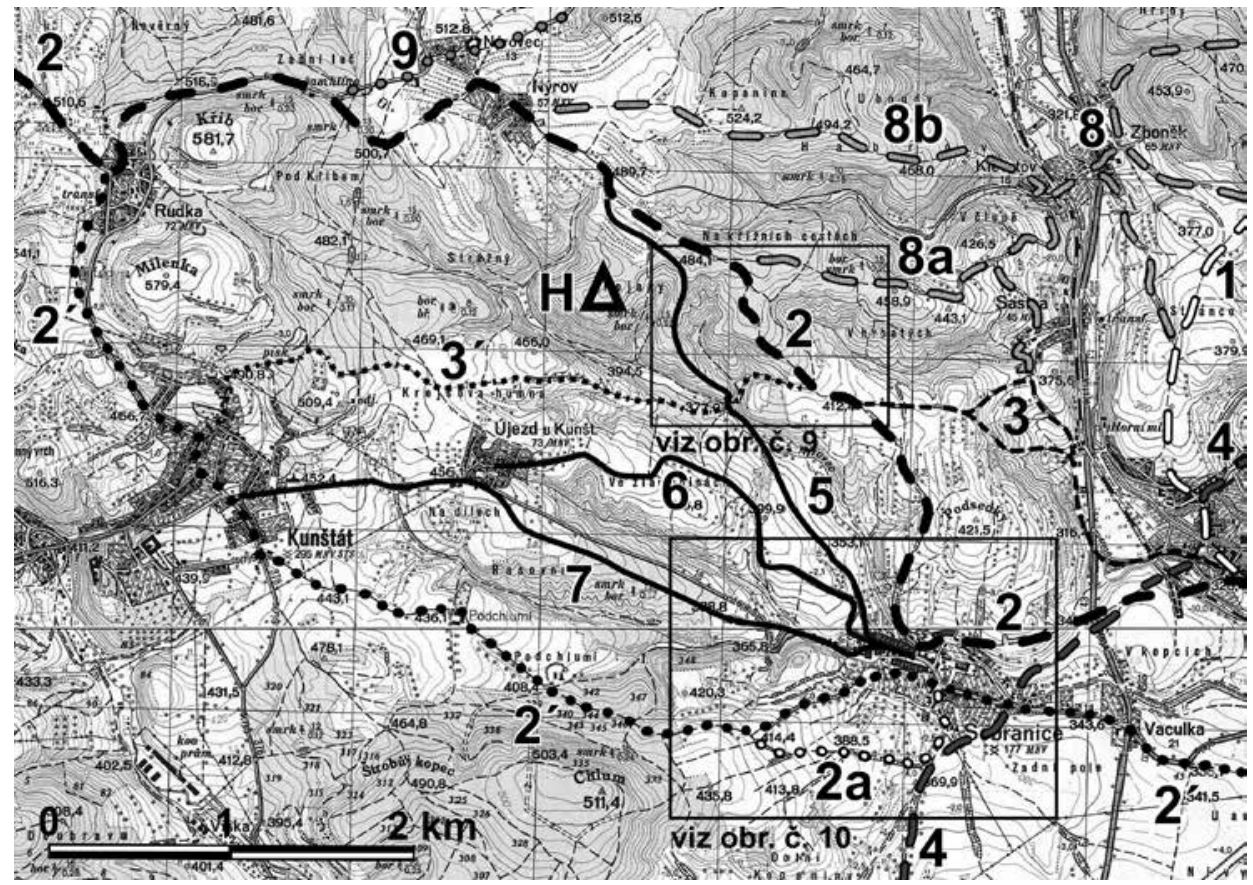

Obr. 7. Zakreslení starých komunikací západně od Svitávky do Topografické mapy $1: 25000$ z roku 1952. H - nedostavěný hrad na Hradisku u Nýrova; 1 - raně středověká severo-jižní trasa (Velké Opatovice-Svitávka-Bořitov); 2 - raně stř̌edověká východo-západní trasa (Boskovice-Svitávka-Polička); 2' - vrcholně středověká spojnice Boskovic s Kunštátem (trasa míjející Svitávku), 2a - odklon cesty do Kunštátu po vysazení sebranické návsi; 3 - cesta vycházející ze svitáveckého náměstí na Sasinu (jako varianta trasy č. 2); 3' - prodloužení trasy (3) do Kunštátu; 4 - vrcholně středověká trasa Lysice-VoděradySvitávka-Jevičko; 5 - cesta Sebranice-Nýrov (kolem Hradiska); 6 - cesta Sebranice-Újezd; 7 - cesta Sebranice-Kunštát; $8,8 \mathrm{a}, 8 \mathrm{~b}$ - cesty, které z východo-západní trasy vyřazují Sebranice i Kunštát; 9 - větev vedená přes Lhotu u Letovic. Mapový podklad http://www.cuzk.cz, cit. 10.9. 2018.

Abb. 7. In eine topographische Karte aus dem Jahr 1952 eingezeichnete alte Verkehrswege westlich von Svitávka, Maßstab 1 : 25 000. H - nicht fertiggestellte Burg auf dem Hügel Hradisko bei Nýrov; 1 - frühmittelalterliche Nord-Süd-Trasse (Velké Opatovice-Svitávka-Bořitov); 2 - frühmittelalterliche Ost-West-Trasse (Boskovice-Svitávka-Polička); 2' - hochmittelalterliche Verbindungslinie zwischen Boskovice und Kunštát (Svitávka auslassende Trasse), 2a - Umleitung des Weges nach Kunštát nach Aussetzung des Dorfplatzes in Sebranice; 3 - vom Marktplatz in Svitávka ausgehender Weg nach Sasina (als Variante von Trasse Nr. 2); 3' - Verlängerung von Trasse (3) nach Kunštát; 4 - hochmittelalterliche Trasse Lysice-Voděrady-Svitávka-Jevíčko; 5 - Weg Sebranice-Nýrov (um Hradisko); 6 - Weg Sebranice-Újezd; 7 - Weg SebraniceKunštát; 8, 8a, 8b - Wege, die aus der Ost-West-Trasse Sebranice und Kunštát aussondern; 9 - durch Lhota bei Letovice geführter Zweig. Kartenunterlage http://www.cuzk.cz, aufgerufen am 10. 9. 2018.

užívané cesty, dobře zachycené na II. vojenském mapování (obr. 5A:1), která dál k severu využívala dopravně neobyčejně př́íhodnou plošinu na rozvodí Svitavy a potoka Semíče.

Po asi dvou kilometrech cesta došla na úpatí Kříbů (454 m) a Křižánku, které se na linii mezi Zboňkem a Míchovem svými jižními svahy zdvíhají nad úroveň zmíněné plošiny o téměř 70 metrů. Trasa od Svitávky se zde rozdělila. Jedna větev vedla víceméně po vrstevnici v jižním svahu Křižánku na východ až severovýchod k jižnímu konci obce Míchov ${ }^{45}$ - jedna strana její trojúhelné návsi je určena dalším pokračováním cesty k severu, ${ }^{46}$ na Podolí. Druhá, strmější větev začala stoupat roklí mezi Kř́by a Křižánky, ze které dodnes zřetelným úvozem v nadmořské výšce $410 \mathrm{~m}$ odbočila na západ, aby přes sedlo Křižánku nacházející se ve výšce $442 \mathrm{~m}$

45 Úvozy na pozicích WGS-84: WGS-84: N49 31.245 E16 36.046; N49 31.257 E16 36.210 (dolů), N49 31.283 E16 36.364 (nahoru).

46 V severním vrcholu míchovské návsi byl v novověku založen velký vrchnostenský dvůr, kvůli němuž cesta nejprve začala náves míjet po východní straně dvora, později vznikl průraz uprostřed severní strany návsi, který umožnil jezdit po západní straně dvora tak, jak z návsi vede i dnešní silnice do Podolí 


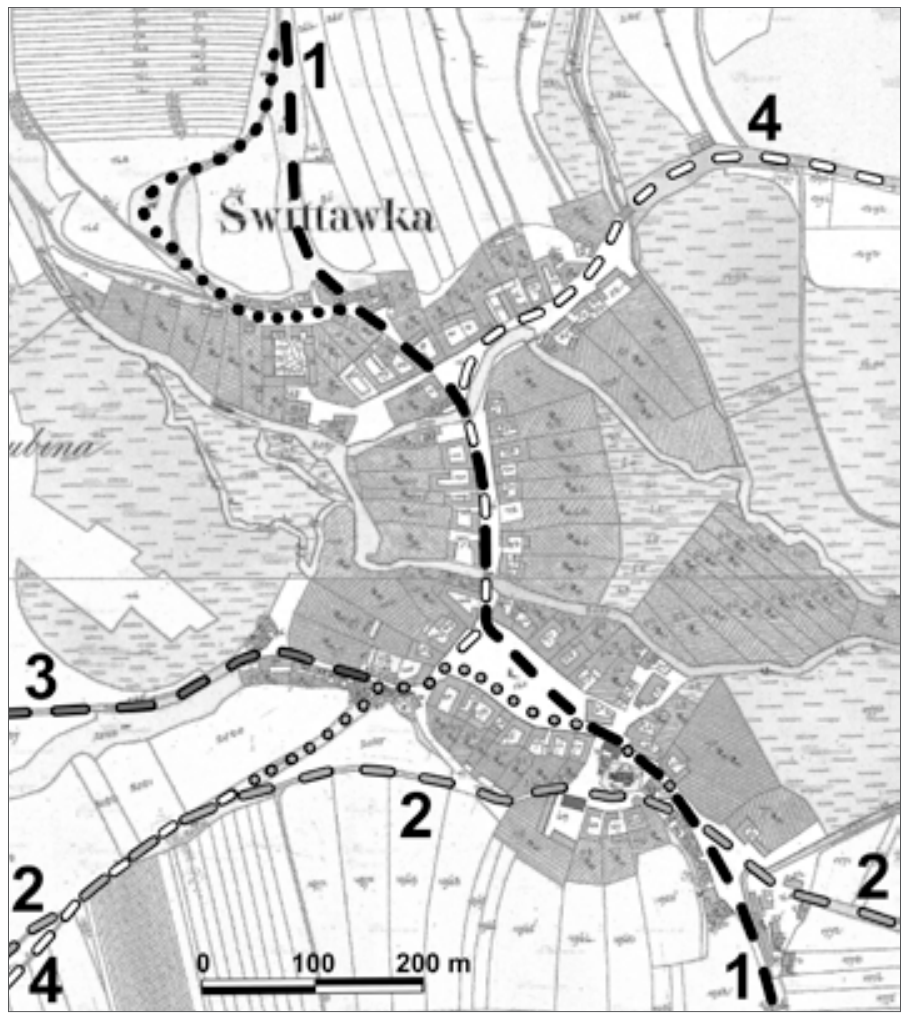

Obr. 8. Situace ve Svitávce zakreslená do mapy Stabilního katastru z roku 1826. 1 - raně středověká severo-jižní trasa Velké Opatovice-Svitávka-Bořitov (tečkovaně mladší voznice); 2 - raně středověká východo-západní trasa Boskovice-Svitávka-Sebranice-Polička (tečkovaně mladší větev přes náměstí); 3 - cesta vycházející ze svitáveckého náměstí na Sasinu (ve směru na Nýrov a Kunštát míjející Sebranice); 4 - vrcholně středověká trasa Lysice-Voděrady-Svitávka-Jevíčko. Mapový podklad http://www.cuzk.cz, cit. 10. 9. 2018. Abb. 8. In eine Karte des Stabilen Katasters aus dem Jahr 1826 eingezeichnete Situation. 1 - frühmittelalterliche Nord-Süd-Trasse Velké Opatovice-Svitávka-Bořitov (gepunktet - jüngere Fuhrwerkstraße); 2 - frühmittelalterliche Ost-West-Trasse Boskovice-Svitávka-Sebranice-Polička (gepunktet - jüngerer Zweig über den Markplatz); 3 - vom Marktplatz in Svitávka ausgehender Weg nach Sasina (in Richtung Nýrov und Kunštát Sebranice auslassend); 4 - hochmittelalterliche Trasse Lysice-Voděrady-Svitávka-Jevíčko. Kartenunterlage http://www.cuzk.cz, aufgerufen am 10. 9. 2018.

došla k Míchovu od západu. Také ona svým pokračováním do Podolí určila trojúhelný tvar návsi Míchova, tentokrát její severní stranu. ${ }^{47}$

V Podolí se na trase od Svitávky nacházelo důležité rozcestí, do směru přes Letovice na Čechy (obr. 5A:1b) a do směru na sever Malé Hané (obr. 5A:1a), ve kterém se procházelo př́ímo pod dodnes částečně dochovaným podolským tvrzištěm (Knies 1904, 154; Nekuda-Unger 1981, 238; Plaček 2001, 494). Stáŕí druhé z uvedených větví by mohl naznačovat románský kostel sv. Michaela Archanděla ve Vískách (Knies 1904, 210-212; Flídr-Konečný-Štěpán 2014, $320-323$, č. 3), ${ }^{48}$ od něhož cesta vedla dál k severu, přičemž asi po $300 \mathrm{~m}$ křižovala významnou

47 K zániku spojení Svitávky s Podolím přes Kříby, Křižánky a Míchov došlo v důsledku vybudování údolní trasy do Letovic, na níž následně vznikla severně od Zboňku odbočka stáčející se k východu a stoupající dodnes zřetelným svazkem úvozů v jižním svahu kopce Boří (430m), odkud již vedla př́ímá cesta do Podolí (obr. 5A:8).

48 Kromě sdruženého věžního okna a částečně dochovaného kvádříkového zdiva je nejvýraznějším pozdně románským prvkem víseckého kostela zazděný portálek v jižní obvodové zdi. 
východo-západní trasu Knínice-Letovice. ${ }^{49}$ Z pozůstatků trasy od Svitávky, dochovaných za touto křižovatkou, se lze domnívat, že pokračovala přes Drválovice na Velké Opatovice. ${ }^{50}$

Pro námi sledované téma jsou důležité nápadné odbočky, které na plošině mezi Svitávkou a úpatím Kř́íbů ze staré trasy ze Svitávky na sever Boskovické brázdy vybíhají ke vsi Zboněk a tamnímu přechodu řeky Svitavy (obr. 5A:6; 7:8). Ve směru od Svitávky, ale i při dopravním pohybu na východo-západní trase, když se z Boskovic využila př́ímá cesta do Míchova (obr. 5B, 5A:5a, 6), umožňovaly vyhnout se Sebranicím i Kunštátu a pokračovat přes Rudku, Ústup a Trpín k Poličce. Z Klevetova (již na sebranickém panství) bylo totiž možné k jihu vystoupat východním svahem údolí Svitavy (obr. 7:8a) a v nadmořské výšce $400 \mathrm{~m}$ se připojit k již popsané hřbetní trase stoupající ze Sasiny (obr. 7:2), o níž víme, že pokračovala do předpolí Hradiska (obr. 7:H). Ale o něco výš proti toku Klevetovského potůčku jiná cesta zahajovala velkým úvozem v severním svahu údolí výstup ke špičce hřbetu, po němž kolem zaniklé vsi Habrov vedla př́má a pohodlná cesta do Nýrova (obr. 7:8b), zakreslená na všech starých mapováních. ${ }^{51}$ Ta již vztah k Hradisku měla mnohem volnější - k jejímu dosažení by osádka hradu musela ujet téměř dva kilometry. Její vznik mohl představovat jeden z faktorů, které přivodily zastavení stavby hradu na Hradisku.

K úplnému vyloučení případného vlivu Hradiska na dopravní pohyb mezi Boskovicemi a Rudkou docházelo ještě u severněji položené trasy. Vícekrát vzpomínaná spojnice Boskovic s Míchovem (obr. 5A:5a) měla prŕímé pokračování do sedla Pusté pole (mezi kótami 442,3 m a 458,9 m - obr. 5A:7), odkud po obou stranách velké erozní rokle Kroupky vedou do údolí Svitavy výrazné úvozové cesty. ${ }^{52}$ Atraktivitu trasy směřující k tomuto přechodu řeky, který se nacházel blíže k Letovicím než ke Zboňku, dokládá její propojení s původní trasou od Svitávky na sever (obr. 5A:1), po němž se v prudkém jižním svahu Kříbů zachoval výrazný systém úvozů, největší v širokém okolí. ${ }^{53}$ Trasa bezpochyby sloužila především ke spojení do Letovic, ale z pravého břehu řeky Svitavy (obr. 5A:7a) bylo možné hlubokým úvozem s několika zákruty vystoupat na hřbet Hranečník (kóta Hora 466,9 m), po kterém tvoříc osu vsi Lhota (příslušné $\mathrm{k}$ letovickému panství) cesta pokračovala na západ kolem Nýroveckého dvora na Rudku (obr. 7:9). Její průchod ve více než dvoukilometrové vzdálenosti od Hradiska již patrně nelze dávat do souvislosti se zahájením stavby hradu a snahou se mu vyhnout.

Kromě možnosti ověřit vypovídací hodnotu starých vojenských mapování přinesl výzkum starých cest v okolí Hradiska u Nýrova několik dalších poznatků. Jestliže v raném středověku ovládala krajinu jižní části Malé Hané fortifikace na Hradisku u Svitávky a do značné míry asi zabezpečovala neměnnost průběhu dálkových komunikací, po jejím zániku můžeme od poloviny 13. století sledovat $\mathrm{v}$ regionu dynamický vývoj, $\mathrm{v}$ rámci kterého na jednotlivých trasách došlo k celé řadě změn, jimiž držitelé okolních panství sledovali své zájmy. Stavba hradu na Hradisku u Nýrova byla zahájena u raně středověké trasy východo-západní komunikace, která přes Drahanskou vrchovinu, Boskovice, Svitávku a Sebranice směřovala po rozvodí Křetínky a jižnějších př́itoků řeky Svitavy na Poličku a dál do Čech. Stavebník zřejmě předpokládal, že do předpolí fortifikace na Hradisku se mu podaří přesměrovat provoz i z variantní, přes Kunštát vedoucí větve komunikace, která se prosadila přibližně v polovině 13 . století, kdy již ve směru od Boskovic bylo možné míjet Svitávku. Na půdorysu Sebranic lze dodnes vysledovat zř̌jmé

49 Na trasu Knínice-Letovice se kvůli př́istupu do Letovic napojovala jak výše uvedená odbočka vycházející z Podolí (obr. 5A:1b), tak v souvislosti s přechodem Semíče pod Bačovem zmíněná prímá cesta od Boskovic (obr. 5B:5b, 5b').

50 Mezi Drválovicemi a Velkými Opatovicemi měla trasa pravděpodobně dvě větve, přes Velkou Roudku a po východním úbočí kopce, na kterém se nacházi opatovické Hradisko (kromě Hradiska se k této větvi patrně váže i významný depot z doby bronzové od Borotína - Salaš 1986, 139-167). K možnému pokračování cesty Svitávka-Míchov-Podolí-Vísky-Drválovice-Velké Opatovice viz výše pozn. 16. Lze uvažovat i o komunikaci, která z Drválovic vedla přes Vanovice na Cetkovice, odkud se také nabízelo několik zajímavých návazností.

51 Ves Habrov se poprvé připomíná v rámci výčtu majetku sebranického panství z roku 1368 (ZDO I, 48 č. 975). K lokalizaci zaniklé vsi viz Tenora (1903, 8), Hosák (1938a, 326) a Sadílek (1997, 220-222).

52 Úvozy na pozicích WGS-84: N49 32.380 E16 35.247 (severní větev); N49 32.262 E16 35.004 (jižní větev).

53 Úvozy na pozicích WGS-84: N49 31.364 E16 35.760. 


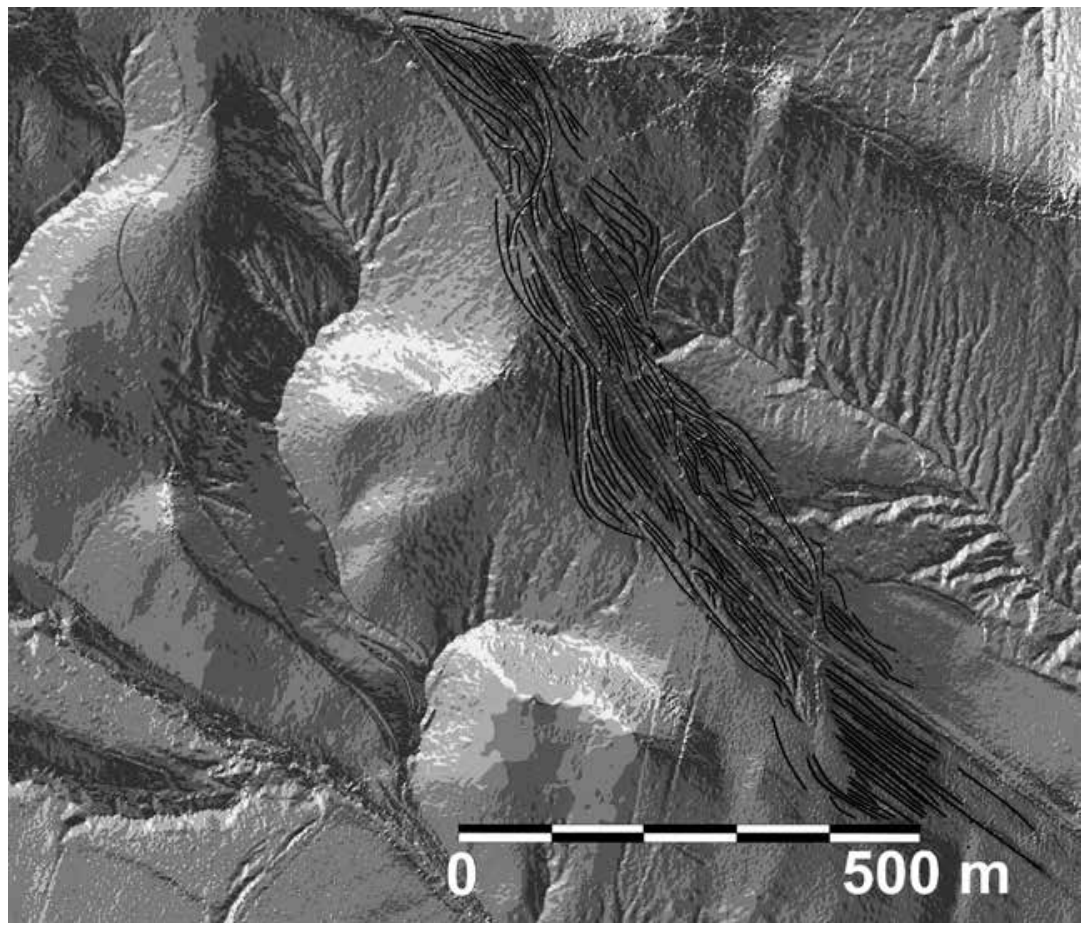

Obr. 9. Rozsáhlý systém úvozů na hřbetu Podsedky, po kterém vedla trasa od Svitávky přes Sebranice na Nýrov (jednotlivé relikty zvýrazněny obtažením). Dobře jsou vidět i velké erozní útvary v bočních svazích okolních hřbetů (LIDAR 5. generace - orientace svahů, http://www.cuzk.cz, cit. 10. 9. 2018). Př́íslušné území je na obr. 7 vyznačeno obdélníkem.

Abb. 9. Ausgedehntes Hohlwegesystem auf dem Bergrücken Podsedky, über den die Trasse von Svitávka über Sebranice nach Nýrov führte (die einzelnen Relikte wurden durch Nachzeichnen hervorgehoben). Gut zu sehen sind auch die Erosionsgebilde an den Seitenhängen der umliegenden Bergrücken (LIDAR 5. Generation - Hangorientierung, http://www.cuzk.cz, aufgerufen am 10. 9. 2018). Das entsprechende Gebiet wurde auf Abb. 7 durch ein Rechteck gekennzeichnet.

snahy držitelů panství, aby veškerý dopravní pohyb od Boskovic do Poličky, at' procházel přes Svitávku, či ji míjel, byl přiveden do předpolí chystaného hradu u Nýrova.

Bylo by možné se ptát, zda v neúspěchu celého podniku se stavbou na Hradisku nesehrála nějakou roli okolnost, že vše by se uskutečňovalo na úkor majitelů sousedního kunštátského panství, pánů erbu vrchních pruhů. Jednalo se přeci o eliminaci Svitávku míjející komunikace, která míŕila přímo do středu náměstí jejich města Kunštátu. Zdálo by se, že pokud v této věci vznik1 mezi rodem pánů z Ceblovic a Kunštáty nějaký konflikt, mohl být urovnán v rámci jejich př́ibuzenských svazků, na které upozorn̆ují Plaček-Futák (2006, 113-114). Jeden z potomků Bohuše z Ceblovic se totiž jmenoval Kuna (CDB V/2, 611 č. 875), stejně jako majitel Kunštátu, a naopak roku 1283 mezi syny Kuny z Kunštátu zase nalézáme Bohuše (RBM II, 563 č. 1305). Ale tyto rodové vazby velmi pravděpodobně sahají do doby, která předcházela založení Hradiska, takže předpoklad zastavení stavby hradu na Hradisku v důsledku nějakých úmluv mezi Kunou z Kunštátu a Bohušem z Ceblovic nejspíše nemá žádnou relevanci, ani oporu v pramenech.

Průzkum starých cest v okolí Hradiska navíc ukázal, že šlo o složitější problematiku, v jejímž rámci je nutno počítat s delším užíváním tras, které dopravní pohyb přiváděly do předpolí rozestavěného hradu na Hradisku. K neutralizaci snah vkládaných držiteli Sebranic do zamýšleného hradu mohl přispět až vznik ze Svitávky (nebo z Boskovic přes Míchov) vedených cest, 


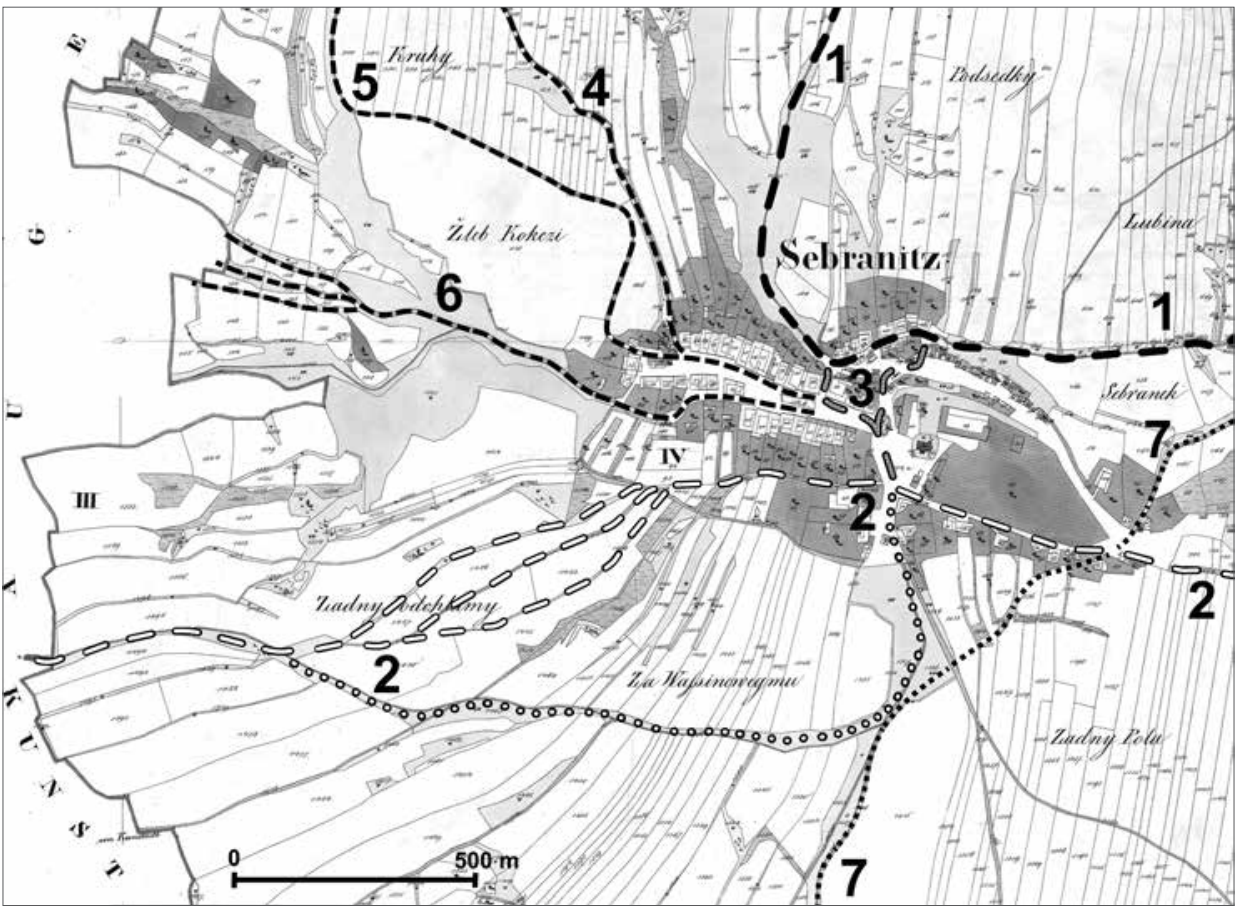

Obr. 10. Situace v Sebranicích zakreslená do mapy Stabilního katastru z roku 1826. 1 - raně středověká východo-západní trasa Boskovice-Svitávka-Sebranice-Rudka; 2 -Svitávku míjející trasa Boskovice-Kunštát (tečkovaně - mladší varianta); 3 - cesty umožňující přes intravilán Sebranic přejít z trasy (2) na trasu (1); 4 - cesta Sebranice-Nýrov (kolem Hradiska); 5 - cesta Sebranice-Újezd; 6 - cesta Sebranice-Kunštát; 7 - cesta Lysice-Svitávka-Jevíčko. Mapový podklad http://www. cuzk.cz, cit. 10.9. 2018.

Abb. 10. In eine Karte des Stabilen Katasters aus dem Jahr 1826 eingezeichnete Situation. 1 - frühmittelalterliche Ost-WestTrasse Boskovice-Svitávka-Sebranice-Rudka; 2 - Svitávka auslassende Trasse Boskovice-Kunštát (gepunktet - jüngere Variante); 3 - Wege, die durch das Intravillan von Sebranice ermöglichen, von Trasse (2) auf Trasse (1) zu wechseln; 4 - Weg Sebranice-Nýrov (um Hradisko); 5 - Weg Sebranice-Újezd; 6 - Weg Sebranice-Kunštát; 7 - Weg Lysice-Svitávka-Jevíčko. Kartenunterlage http://www.cuzk.cz, aufgerufen am 10. 9. 2018.

umožňujících za řekou Svitavou po výstupu na hřbety Habrov a Hranečník pokračovat na Rudku v již větším odstupu od Hradiska. Kromě možných vlivů držitelů boskovického a letovického panství tušíme v pozadí práci hradišt’ských premonstrátů, kterým v kritickém období patřila nejen Svitávka, ale i klíčové lokality Míchov a Zboněk. Ne nadarmo Zboněk a Míchov jako příslušenství Svitávky nechali někdy v 80. až 90 . letech 13. století mniši zapsat do falza stvrzujícího jim držení trhové vsi Svitávky již k roku 1201 (CDB II, 365-367 č. 352; Šebánek-Dušková 1952, 65 , pozn. 2).

Držitelé Sebranic se pak museli spokojit s tím, že východo-západní komunikace mezi Boskovicemi a Kunštátem procházela přes nově vytyčenou náves v Sebranicích, z níž vedli přímou cestu do Kunštátu (obr. 7:7; 10:6), ${ }^{54}$ zatímco předchozí Svitávku míjející a přes jižní část Sebranic procházející trasa, která na úbočí kopce Chlum tvořila hranici sebranického panství, byla do středu Sebranic přivedena širokým obloukem (obr. 7:2a; 10:2 - tečkovaně) - patrně proto, aby se uvolnil prostor pro humna domů vznikajících po jižní straně návsi. ${ }^{55}$ Ze všeho je zřejmé,

54 Na úvozy této cesty (ze sebranické návsi do Kunštátu), táhnoucí se podél dnešní silnice č. 19 Sebranice-Kunštát (na pozici WGS-84: N49 30.034 E16 33.456), bylo upozorněno již dříve, ale byly nesprávně pokládány za pozůstatky hraniční cesty z břevnovského falza k roku 1043 (srov. Bolina 2009, 386).

55 Situace Sebranic a půdorysné uspořádání této návsi vybízí k otázce, zda se zde nechystalo vysazení městečka. 
že založení a opuštění rozestavěného Hradiska u Nýrova bylo sice krátkodobou záležitostí, ale tu pro souvislost s lokací návsi Sebranic i vesnic Nýrova a Újezdu nelze promítat do časového intervalu omezeného jen na několik málo let mezi tím, kdy Bohuš z Ceblovic roku 1258 získal sebranický újezd od břevnovského kláštera, a 60. lety 13. století, kdy již měl hodnost moravského maršálka, či začal působit jako přerovský kastelán (CDB V/1, 584 č. 392; V/2, 74 č. 525). Ona bezpochyby s lokací sebranické návsi související epizoda s Hradiskem se mohla odehrát kdykoliv ve třech desetiletích, po která od konce 50. let 13. století Bohuš dál ještě žil (srov. RBM II, 602 č. 1399; 622 č. 1448), či možná ji lze omezovat až přelomem 13. a 14. století, když ze vztahu k Sebranicím nevyloučíme Bohušovy potomky, k čemuž ani žádná indicie neexistuje. ${ }^{56}$

Poznatky o starých cestách nám také umožnily nahlédnout do problematiky „,eelního sazebníku“ ve falzu listiny kláštera Hradisko k roku 1250, který reagoval na situaci vzniklou po zániku raně středověkého Hradiska nad Svitávkou, když tato lokalita ztratila svou někdejší centrální funkci. Viděli jsme, jak z trasy Boskovice-Polička již dřive Svitávku vyřadila cesta vedená od Mladkova přes jižní část Sebranic přímo na Kunštát a že sami hradišt’̌stí premonstráti nejspíš podpořili využívání komunikace Boskovice-Míchov-Zboněk. Pak je vcelku pochopitelné mlčení falza k roku 1250 o tom, že by se ve Svitávce vybíralo mýto na východo-západní trase. Nezodpovězená zatím zůstává otázka, zda po roce 1270, kdy listina vznikla, si hradiššští premonstráti „sazebníkem“ skutečně nárokovali vybírání mýta v širokém okolí Svitávky, nebo jen př́islušnými formulacemi chtěli dokládat stáŕí mýtního práva pro samotnou Svitávku.

I když o řadě zjištění předložených v tomto př́íspěvku je možno diskutovat, podařilo se snad na př́kladu Hradiska u Nýrova v dostatečné míre ukázat, že výzkum starých cest představuje nepominutelný pramen historického poznání, který zejména $\mathrm{v}$ př́ípadě absence jiných zdrojů informací má potenciál odkrývat dříve neznámé souvislosti, nebo alespoň nás přivést k otázkám, jež dříve nebylo možné si položit. Zjištování komunikačních vztahů by mělo být součástí každé detailnější práce o kterékoliv fortifikaci.

Staré cesty jsou však zároveň pramenem zdaleka nejvíc do budoucna ohroženým. Neuváženými zásahy mizí v polích i intravilánech obcí staré úvozové cesty, celé svazky úvozů jsou ničeny v lesích, nebot’ těžebním společnostem ztěžují svážení dřeva těžkou technikou. I když na mnohých z dochovaných reliktů se dopravní pohyb odehrával před řadou staletí, někdy dokonce tisíciletí, jen zanedbatelnému počtu z nich se doposud dostalo památkové ochrany.

\section{Prameny a literatura}

BOLINA, P., 1988: Jádro drahotušského hradu - The core area of the Drahotuše castle, Sborník kruhu přátel Muzeahl. města Prahy 1, 157-167.

- 2005: Byl hrad Svojanov u Poličky posledním centrem tzv. úsobrnské provincie? (Př́spěvek k historii moravsko-českého pomezí II.) - War die Burg Swojanow das letzte Zentrum Provinz Úsobrno? (Ein Beitrag zur Geschichte des böhmisch-mahrischen Grenz-landes, Teil II), ČMM 124, 3-46.

- 2009: Postupy při kolonizaci: vytyčování „újezdơ“. In: Přemyslovci. Budování českého státu (Sommer, P.Třšśík, D.-Žemlička, J., edd.), 384-386. Praha.

BOLINA, P.-CENDELÍN, D., v tisku: K vypovídací schopnosti vztahu fortifikací a dálkových cest na př́ikladu výrazné koncentrace hradů v oblasti SZ od Brna, Svorník 15.

BOLINA, P.-ŠLÉZAR, P., 2006: K problematice falz vzniklých při majetkových sporech hradišs’ského kláštera na severu Drahanské vrchoviny - Zur Problematik der bei Eigentumsstreitigkeiten des Klosters Hradischt im Norden der Drahaner Höhe entstandenen Fälschungen, ČMM 125, 307-342.

BOLINA, P.-KLIMEK, T.-CÍLEK, V., 2018: Staré cesty v krajině středních Čech. Praha.

CENDELÍN, D.-BOLINA, P.-ADAM, D., 2010: Jevíčko na cestě z Prahy do Olomouce v období raného středověku (úsek Litomyšl-Konice). Jevíčko.

CDB I: Codex diplomaticus et epistolaris Regni Bohemiae I, 805-1197 (Friedrich, G., ed.). Pragae 1907.

56 Ke čtyřem Bohušovým synům viz CDB V/2, 611 č. 875; Pilnáček (1930, 408); nutno upozornit, že nic není známo o tom, kdy a jak v devadesátiletém období po roce 1258 se sebranické panství stalo majetkem pánů z Boskovic (v jejich rukách poprvé doloženo roku 1348 - ZDO I, 2 č. 23). 
CDB II: Codex diplomaticus et epistolarius regni Bohemiae II, 1198-1230 (Friedrich, G., ed.). Pragae 1912.

CDB IV: Codex diplomaticus et epistolarius regni Bohemiae IV, 1245-1253 (Šebánek, J.-Dušková, S., edd.). Pragae 1962.

CDB V/1: Codex diplomaticus et epistolaris Bohemiae V/1, 1253-1266 (Šebánek, J.-Dušková, S., edd.). Pragae 1974.

CDB V/2: Codex diplomaticus et epistolaris Bohemiae V/2, 1267-1278 (Šebánek, J.-Dušková, S., edd.). Pragae 1981.

DOLEŽEL, J., 2003: K etnické struktuře středověké kolonizace Drahanské vrchoviny - Zur ethnischen Struktur mittelalterlichen Kolonisation des Drahanská vrchovina (Drahaner Höhe), AH 28, 123-173.

ELIÁŠ, J., 1996: Pozdně románské jádro zámku Kunštátu a jeho přestavba - Spättromanischer kern des Schlosses Kunštát und sein Umbau, CB 5, 107-118.

FLÍDR, A.-KONEČNÝ, M.-ŠTĚPÁN, R., 2014: Průvodce krajinou hradů. Středověké památky v povodí Svratky a Svitavy. Kroměříž.

HOSÁK, L., 1931: Dějiny Boskovska I. Do válek husitských. Boskovice.

- 1937: Př́íspěvky k starému rodopisu moravskému IV. Erb křídla, ČSPS 45, 63-69.

- 1938: Příspěvky k starému rodopisu moravskému VIII. Erb dvou beraních rohů, ČSPS 46, 107-111.

- 1938a: Historický místopis Země moravskoslezské. Praha.

- 1964: Historický místopis hradského obvodu olomouckého do poloviny 14. století, Sborník prací historických. Acta Universitatis Palackianae Olomucensis facultas philosophica 22. Historica VI, 45-89.

- 1965: Historický místopis okresu Blansko v období feudalismu. Blansko.

HOSÁK, L.-ŠRÁMEK, R., 1980: Místní jména na Moravě a ve Slezsku II. M-Ž. Praha.

JANIŠ, D.-VRLA, R., 2010: Hrad Komňa (Zuvačov) - jeho historie a stavební podoba - Die Burg Komňa (Zuvačov) - ihre Geschichte und Baugestaltung, CB 12, 359-368.

JARU゚ŠKOVÁ, Z.-ŠTROF, A., edd., 2014: Pravěk Boskovicka - Prehistory of the Boskovice Region - Urgeschichte des Landes um Boskovice. Boskovice.

KEJ ̌̌, J., 1998: Vznik městského zřízení v českých zemích. Praha.

KOLAŘÍK, V.-MERTA, D.-POKORNÝ, J., 2014: Bývalá rychta v Sebranicích čp. 36. Počátek systematického výzkumu vesnické usedlosti, Dějiny staveb 2014. Sborník příspěvků z konference Dějiny staveb (Mikota, P., ed.), 211-220. Plzeň.

KNIES, J., 1904: Vlastivěda moravská. II. Místopis, Boskovský okres. Brno.

KUČA, K., 1996: Města a městečka v Čechách na Moravě a ve Slezsku I. (A-G). Praha.

- 1997: Města a městečka v Čechách, na Moravě a ve Slezsku II. (H-Kole). Praha.

- 2008: Města a městečka v Čechách na Moravě a ve Slezsku, VII. (Str-U). Praha.

KOSMAS, BRETHOLZ: Cosmae Pragensis Chrinica Boemorum, Monumenta Germaniae historica. Scriptores rerum Germanicarum. Nova series, Tomus II, Anhang IV (Bretholz, B., ed.). Berlin 1923.

MACKERLE, J., 1958: Letopis města Jevíčka. Brno.

MARTÍNEK, J., a kol., 2013: Moderní metody identifikace a popisu historických cest. Metodická př́iručka. Brno. Dostupné z: http://invenio.nusl.cz/record/204334/files/nusl-204334_1.pdf?version=1, cit. 6. 6. 2018.

NEKUDA, V.-UNGER, J., 1981: Hrádky a tvrze na Moravě. Brno.

NOVÁK, J., 2016: Zeměpanské hrady na Moravě ve 2. polovině 13. století. Pokus o revizní výzkum. Bakalářská diplomová práce, ulož. v Historickém ústavu FF MU, Brno, vedoucí práce L. Jan.

NOVÁK, M., 2015: Opevněné výšinné sídliště na „Malém Chlumu“ u Krhova a jeho zázemí v pozdní době bronzové a v době halštatské - Fortified hilltop settlement Krhov „Malý Chlum“ and its hinterland in the Late Bronze Age and Hallstatt period. Pravěk - Supplementum 31. Brno.

NOVÝ, R., 1991: Diplomatické poznámky k donačním listinám českých klášterů a kapitul do konce 12. Století - Diplomatische Bemerkungen zu den Donationsurkunden der bohmischen Kloster und Kapitel bis zum Ende des 12. Jahrhunderts, Studia mediaevalia Pragensia 2, 125-146.

PAPAJÍK, D., 2007: Páni z Holštejna. Významný, ale zapomenutý panský rod. České Budějovice.

PILNÁČEK, J., 1930: Staromoravští rodové. Wien.

PLAČEK, M., 1987: Sídlištní struktura a hrady v povodí Loučky (Bobrůvky). In: XVI. Mikulovské sympozium 1986, 245-255. Praha.

- 1988: K vývoji hradů v povodí Svitavy - Zur Entwicklung der Burgen im Flusgebiet Svitava, AH 13, 307-320.

- 1995: K objevu pozdně románského paláce na zámku Kunštátě a nástin vývoje hradu do začátku 16. Století - Zur Entdeckung eines spätromanischen Palastes auf dem Schloss in Kunštát und Umriss der Burgentwicklung bis Anfang des 16. Jahrhunderts, PRP 1995, č. 1, 37-48.

- 2001: Ilustrovaná encyklopedie moravských hradů, hrádků a tvrzí. Praha. 
- 2010: Znojemský kastelán Boček a jeho bratři ve službách Přemysla Otakara II. In: Jan, L.-Kacetl, J. a kol., Pocta králi. K 730. výročí smrti českého krále, rakouského vévody a moravského markraběte Přemysla Otakara II., 81-91. Brno - Znojmo.

PLAČEK, M.-FUTÁK, P., 2006: Páni z Kunštátu. Rod erbu vrchních pruhů na cestě k trůnu. Praha.

PROCHÁZKA, R.-PLAČEK, M., 1985: Hrad v Doubravici nad Svitavou a jeho feudální državy, Regionální sborník okresu Blansko '85, 75-79.

PROCHÁZKA, R., 1989: Povrchový průzkum u kostela sv. Bartoloměje v Jevíčku (okr. Svitavy), PV 1986, s. 65-66.

- 1994: Svitávka-Hradisko v 11.-15. stol. - Svitávka-Burgstädte im 11.-15. Jahrhundert, CB 4, $231-236$.

PROCHÁZKA, R.-ŠTROF, A., 1983: Příspěvek k osídlení Bořitova a Černé Hory na Blanensku - Zur Besiudlungsentwicklung von Bořitov und Černá Hora in der Gegend Blansko, VVM XXXV, 46-58.

RBM II: Regesta diplomatica nec non epistolaria Bohemiae et Moraviae, Pars II (1253-1310) (Emler, J., ed.). Pragae 1882 .

RICHTER, V., 1955: Staré stezky na Moravském Třebovsku, ČSPS 63, 193-203.

SADÍLEK, J., 1997: Nýrov (okr. Blansko). „Habrov“, Habrův žleb“. Zaniklá stř̌edověká ves, PV 1993-1994, $220-222$.

SALAŠ, M., 1986: Hromadný nález bronzové industrie z Borotína, okr. Blansko - Der Hortfund von Bronzeindustrie aus Borotín, Bez. Blansko, AR XXXVIII, 139-167.

SEDLÁČEK, A., 1918: Dodatek o újezdě Sebranickém, ČC̆H 24, 272-273.

- 1925: Českomoravská heraldika. Část zvláštní. Praha.

SEVERIN, K., 2000: Trstenickou stezkou cestou necestou (K vývoji názorů na průběh středověké komunikace), Pomezí Čech a Moravy. Sborník prací ze společenských a přírodních věd pro okres Svitavy, Svazek 4, 353-388.

- 2003: Kolonizace Hřebečska - Die Kolonisation des Schönhengsten, AH 28, 175-210.

SLOUKA, R., 2005: Raně středověké osídlení Třebíčska v tzv. brněnském údělu, Západní Morava 9, 5-23.

SMETÁNKA, Z.-ŠKKABRADA, J., 1976: K metodice studia půdorysu české raně středověké vesnice - Zur Methodik des Studiums der Grundrisse frühmittelalterlicher Darier, AH 1, 55-60.

ŠEBÁNEK, J., 1953: K otázce břevnovských falz. In: Šebánek, J.-Dušková, S., Studie k českému diplomatáři I, SPFFBU II, č. 2-4, 261-285.

- 1962: Třri nejstarší doklady o Vsetíně, SPFFBU C 10, č. 8, 1961, 77-93.

ŠEBÁNEK, J.-DUŠKOVÁ, S., 1952: Kritický komentář k moravskému diplomatáři. Praha.

ŠIMÁK, J. V., 1917: Ještě o Hrutově a stezce Trstenické, ČČH 23, 157-171.

ŠIMEČEK, P., 2011: Zrození hradu. K technologii počáteční fáze nedokončeného hradu u Újezdu u Kunštátu - Die Geburt einer Burg. Der unvollendete Bau der Burg in Újezd u Kunšttátu. In: Hrad jako technický problém. Technologie a formy výstavby středověkých opevněných sídel. Archaeologia Mediaevalia Moravica et Silesiana 2 (Měř́nský, Z., ed.), 117-121. Brno.

ŠTROF, A., 1987: Pokračování výzkumu na halštatském hradišti Malý Chlum mezi Krhovem a Oborou (okr. Blansko), PV 1984, 33.

- 1987a: Sondáž na Hradisku u Újezda u Kunštátu (okr. Blansko) - Tastgrabung auf Hradisko bei Újezd bei Kunštát (Bez. Blansko), PV 1984, 87.

- 1990: Výzkum hradiska u Svitávky v roce 1987 (okr. Blansko) - Erforschung von Hradisko bei Svitávka im Jahre 1987 (Bez. Blansko), PV 1987, 94-95.

- 1993: Die Erforschung von Hradisko (Burgwall) bei Svitávka im J. 1990 (Bez. Blansko), PV 35, 1990, 133-134.

- 1993a: Záchranný výzkum na Hradisku u Skalice (okr. Blansko), PV 36, 1991, 59.

TENORA, J., 1885: Dějiny městečka Kunštátu. Brno.

- 1903: Vlastivěda moravská II. Kunštátský okres. Brno.

TRAMPLER, R., 1903-1904: Die Herren von Holstein, Zeitschrift des Vereines für die Geschichte Mährens und Schlesiens 7, 282-341; 8, 47-118.

VARHANÍK, J., 2012: Velké okrouhlé věže hradů v českých zemích - Big round towers in the Czech lands, Monumentorum Tutela - Ochrana pamiatok 24, 299-307.

VÁVRA, I., 1971: Trstenická stezka - Der Trstenicer Steig, HG 6, 77-132.

VELÍMSKÝ, T., 2002: Hrabišici. Páni z Rýzmburka. Praha.

VÍCH, D., 2001: Povrchová prospekce severní části Boskovické brázdy v letech 1997-2000 - Surface prospecting in the northern part of the Boskovice Graben in years 1997-2000, ZMHK 27, 27-56.

- 2005: Povrchová prospekce severní části Boskovické brázdy v roce 2004 - Surface prospecting in the northern part of the Boskovice Graben in the year 2004, ZMHK 31, 32-50. 
- 2013: Výzkum středověké jímky na Palackého náměstí v Jevíčku - The investigation of a medieval cesspit in Palacký Square in Jevíčko, AVČ 5, 112-147.

VÍCH, D.-JÍLEK, J., 2016: Hrob nebo depot? Nález z doby římské u Jevíčka (okr. Svitavy) - A grave or a hoard? A Roman-period find near Jevíčko, Svitavy district, Czech Republic, AR LXVIII, 363-380.

WIHODA, M., 1992: K problematice šilperského fojtského privilegia a jeho vzniku v roce 1278 - Zur Problematik des Vogtprivilegs von Šilperk und seiner Entstehung im Jahre 1278, ČMM 111, 3-11.

ZAPLETALOVÁ, D., 2016: Počátky rajhradského kláštera - monastické nebo kolegiátní? - The Foundation of the Rajhrad Cloister - Monastic or Collegiate, Studia Mediaevalia Bohemica 8, 219-245.

ZDO: Die Landtafel des Markgrafthumes Mähren. Text der Olomützer Cuda, (Chlumecky, P.-Chytil, J.Demuth, C.-Wolfskron, A., edd.). Brünn 1856.

ŽEMLIČKA, J., 1998: „Právo nucené směny“ při zakládání stř̌edověkých měst - „Das Rechts des Zwangaustausch“ bei der Gründung mittelalterlicher Städte, ČČH 96, 502-531.

\section{Zusammenfassung}

\section{Die nicht zu Ende gebaute Burg auf dem Hügel Hradisko (Bezirk Blansko) im Lichte der Erforschung alter Wege in der Umgebung der Gemeinde Svitávka}

Am Beispiel des Hügels Hradisko bei der Gemeinde Nýrov versucht der Verfasser aufzuzeigen, dass die Erforschung alter Wege eine nicht zu vernachlässigende Quelle für historische Erkenntnisse darstellt, die besonders bei fehlenden anderen Informationsquellen über ein Potenzial verfügt, früher unbekannte Zusammenhänge aufzudecken. Wenn den bei archäologischen Grabungen gemachten Feststellungen zufolge die Landschaft des südlichen Teils der Kleinen Hanna von der Befestigungsanlage auf dem Hügel Hradisko bei der Ortschaft Svitávky (Abb. 5A:4) beherrscht wurde und wohl in beträchtlichem Maße den unverändert gebliebenen Verlauf der Fernwege gewährleistete, können wir ab dem 13. Jahrhundert in der Region nach ihrem Untergang eine dynamische Entwicklung beobachten, in deren Rahmen es auf den einzelnen Trassen zu einer Reihe von Veränderungen kam, mit denen die Besitzer der umliegenden Herrschaften ihre Interessen verfolgten. Bohuš von Ceblovice (CDB V/1, 238-239 Nr. 149) begann nach dem Jahr 1258 auf der frühmittelalterlichen Trasse des Ost-West-Verkehrsweges (Abb. 7:2), der über das Drahaner Bergland, Boskovice, Svitávka, Sebranice und Rudka in Richtung Wasserscheide Křetinka und der südlicheren Nebenflüsse des Flusses Svitava und hinter ihm nach Polička und weiter nach Böhmen verlief, damit, auf dem Hügel Hradisko bei Nýrov eine Burg zu errichten (Abb. 7:H). In der Fälschung einer Urkunde zum Jahr 1073 wurde dieser Verkehrsweg als „via publica“ erfasst (CDB I, 370 Nr. 386). Der Bauherr hat offenbar angenommen, dass es ihm gelingt, auch den Verkehr von einem neuen Zweig des durch Kunštát führenden Verkehrsweges in das Vorfeld der Befestigungsanlage auf dem Hügel Hradisko umzuleiten, der sich ungefähr Mitte des 13. Jahrhunderts durchgesetzt hatte, als es schon von Boskovice aus möglich war, die Ortschaft Svitávka zu umgehen (Abb. 7:2'). Diese neue Trasse taucht in der Fälschung einer Urkunde zum Jahr 1043 auf, die nach 1250 entstanden war (CDB I, 351-352 Nr. 378). Am Grundriss von Sebranice kann man bis heute das offenkundige Bestreben der Besitzer der Herrschaft erkennen, jedwede Verkehrsbewegung von Boskovice nach Polička, ob sie nun durch Svitávka führte oder nicht, in das Vorfeld der bei Nýrov vorbereiteten Burg zu lenken (Abb. 10:3, 4).

$\mathrm{Zu}$ einer Neutralisierung der von den Besitzern von Sebranice für die beabsichtigte Burg aufgebrachten Bemühungen konnte erst die Entstehung der von Svitávka (oder von Boskovice über Míchov) aus geführten Wege verhelfen, die es hinter dem Fluss Svitava nach dem Besteigen der Bergrücken Habrov und Hranečník einem Reisenden ermöglichten, seinen Weg nach Rudka in einem schon größeren Abstand von Hradisko fortzusetzen (Abb. 5A:6, 7; 7:8b, 9). Außer möglichen Einflüssen der Herren von Boskowitz und der Herren von Letowitz vermuten wir im Hintergrund das Betreiben der Prämonstratenser aus dem Kloster Hradisch, denen in dem kritischen Zeitraum nicht nur Svitávka sondern auch die Schlüsselstandorte Michov und Zboněk gehörten. Nicht umsonst ließen die Mönche Svitávka irgendwann in den achtziger und neunziger 
Jahren des 13. Jahrhunderts in die Fälschung einer Urkunde eintragen, die ihnen den Besitz des Marktdorfes Svitávka bereits zum Jahr 1201 bestätigte (CDB II, 365-367 Nr. 352).

Die Besitzer von Sebranice mussten sich dann damit zufriedengeben, dass der Ost-West-Verkehrsweg zwischen Boskovice und Kunštát durch den neu abgesteckten Dorfplatz in Sebranice führte, von wo aus sie ihn auf direktem Wege nach Kunštát lenkten (Abb. 7:7; 10:6), während die vorherige, Svitávka auslassende und durch den südlichen Teil von Sebranice führende Trasse, die am Hang des Hügels Chlum die Grenze der Herrschaft Sebranice bildete, in einem breiten Bogen ins Zentrum von Sebranice gelenkt wurde (Abb. 7:2a; 10:2 - gepunktet) - dies offenbar deshalb, damit Raum geschaffen wurde für die Tennen der auf der Südseite des Dorfplatzes entstehenden Häuser. Aus all dem wird offensichtlich, dass die Gründung und Aufgabe der sich im Bau befindlichen Burg Hradisko bei Nýrov zwar eine kurzfristige Angelegenheit war, sie jedoch wegen dem Zusammenhang mit der Lokation des Dorfplatzes von Sebranice und der Dörfer Nýrov und Újezd nicht in das nur auf die wenigen Jahre dazwischen begrenzte Zeitintervall projiziert werden kann, als Bohuš von Ceblovice im Jahr 1258 vom Kloster Břevnov die Umreit Sebranice erwarb und den sechziger Jahren des 13. Jahrhunderts, als er bereits den Rang eines mährischen Marschalls besaß, bzw. als Kastellan von Přerov zu wirken begann (CDB V/1, 584 Nr. 392; V/2, 74 Nr. 525). Jene, zweifellos mit der Lokation des Dorfplatzes von Sebranice zusammenhängende Episode von Hradisko hat sich irgendwann in den drei Jahrzehnten abspielen können, nach denen Bohuš ab Ende der fünfziger Jahre des 13. Jahrhunderts noch weiterlebte (vgl. RBM II, 602 Nr. 1399; 622 Nr. 1448), bzw. könnte erst auf die Wende des 13. und 14. Jahrhunderts begrenzt werden, wenn man die Nachfahren von Bohuš von einem Bezug zu Sebranice nicht ausschließt, wofür es kein einziges Indiz gibt.

Die Erkenntnisse über die alten Wege ermöglichen es uns auch, eine Problematik zu betrachten, die, gemäß der Fälschung der Urkunde des Hradischer Klosters zum Jahr 1250 (CDB IV, 344 Nr. 188) nach dem Untergang des frühmittelalterlichen Burgstalls Hradisko oberhalb von Svitávka vom dortigen Mauterheber geklärt werden musste, als dieser Standort seine einstige zentrale Funktion eingebüßt hatte. Außer der Tatsache, dass der von Mladkov durch den südlichen Teil von Sebranice direkt nach Kunštát führende Weg Svitávka auf der Trasse Boskovice-Polička früher schon ausgelassen hatte (Abb. 6:2'), haben die Hradischer Prämonstratenser eine Nutzung des Verkehrsweges Boskovice-Míchov-Zboněk (Abb. 5A:5a, 6) eher unterstützt, die es ermöglichte, sowohl Kunštát, als auch vor allem Sebranice und das zu ihm gehörende Hradisko bei Nýrov auszuweichen. Dann ist gut nachvollziehbar, dass die Fälschung zum Jahr 1250 darüber schweigt, dass man auf der Ost-West-Trasse in Svitávka Maut erheben würde. Die Erhebung einer Maut direkt in Svitávka war dann nur mit der Nord-Süd-Trasse verbunden (Abb. 4:1; 5A:1, 1a), deren Verlauf man, ebenso wie die Art und Weise, wie Reisende Svitávka ausgewichen sind, ziemlich genau bestimmen konnte (Abb. 4:4; 5B:1'). Offen bleibt vorerst die Frage, ob die Hradischer Prämonstratenser nach 1270, also als die Fälschung zum Jahr 1250 entstand, mit einem „Tarifbuch“ in der weiteren Umgebung von Svitávka tatsächlich Anspruch auf die Erhebung einer Maut erhoben, oder ob sie mit den entsprechenden Formulierungen lediglich das alte Mautrecht nur für Svitávka belegten, um das es ihnen vor allem gegangen sein muss.

Ing. Pavel Bolina, Ph.D., V Úvoze 245/12, 15900 Praha 5, Česká republika, bolinapavel@gmail.com 
